\title{
Tracing Paleotsunami signatures on central part of east coast of TamilNadu by using granulometric analysis
}

\author{
N.Muthukrishnan, \\ Department of Civil Engineering, Shivani Institute \\ of Technology, Trichy, TamilNadu, India.
}

\author{
R.Sivasamandy, \\ Department of Civil Engineering, OAS \\ Engineering college, Thuraiyur, TamilNadu, India.
}

\begin{abstract}
The Trench samples collected at five places like Chandrapadi, Manickabangu, Pillaiperumalnallur, Chinnamedu and Vanagiri areas of east coast of Tamilnadu, India were analysed for tracing paleotsunami signatures. The importance was given because these areas were highly affected both by frequent occurrence of storm surges and tsunami. An attempt was made by making trenches at five locations next to coastal dunes on seaward side upto the depth of watertable to find the specific type of layers. The areas like Vanagiri, Chinnamedu having three evidences of tsunami event including the recent tsunami occurred on $26^{\text {th }}$ of December 2004 whereas Manickabangu and Pillaiperumanallur shows two signatures but at the same time Chandrapadi location having only one at the top and the remaining two are below the hard lateritised layers. This has been suspected that the coast may have undergone a long period of exposure for weathering that is why they may not be comparable with that of other locations. The exact date may be deciphered once after OSL $\mathrm{C}^{14}$ dating in these regions.
\end{abstract}

Keywords: Bay of Bengal, Paleotsunami, Tsunami signature, East coast of India

\section{Introduction}

The west coast of India had affected by limited number of tsunami events (Rajamanickam and Prithviraj 2006). Some of the researchers made study on tsunami related deposits named as tsunamites (Shanmugam 2006) and the term was utilized by the consequent researchers done in the west coast (Rajendran et al. 2006). Once after tsunami occurred in the east coast of India on $26^{\text {th }}$ Dec 2004 there were so many researches went on in that area about damage assessment, grain size analysis, heavy mineral analysis, water contamination analysis and so on among which one of the study on tsunami made between Rameswaram and Thoothukudi (Singarasubramanian, et al. 2006) observed that dunes were breached, erosional channels were created, inundation sedimentation thickness ranges from 1 to $30 \mathrm{~cm}$ and the areal extend was up to 10 to $100 \mathrm{~m}$ from shoreline. Fine sediments with layering were deposited over the eroded surface along the cost. The thickness of fresh dark colored sediments deposited over the coarser fragments was about $30 \mathrm{~cm}$ revealed that thinning out towards landside and were dark gray in color enriched with heavy minerals. Tsunami deposits have multiple graded beds within the deposition by successive tsunami waves (Moore 2000).

The tsunami events were evidently proved that they occurred in four stages (i) lower layer mixed with beach and terrigenous sands, (ii) Overlain by thick coarse poorly sorted sand, (iii) Followed by angular deformed beach sand with coarse grains and (iv) finally the badly sorted coarse grained outwash deposits. Lower layer was enriched with heavy minerals derived from marine environment and other two were by tsunami run up. Final one was the backwash of tsunami from distal inundations (Barbara Keating et. al., 2004). Tsunami deposits were believed to be loosely consolidated water saturated sand and silt with poor sorting (Dzulynski 1966). The most common tsunami deposits were fine sediments that most frequently occur as sediment sheets. Once after the tsunami deposits occur in varying dimensions it undergoes further reworking by means of consecutive wave action, mixing up of later sediments or by denudation due to natural agencies like streams, wind, rain and also biogenic activities (Srinivasalu 2009). Thinning out of the tsunami layer also observed even within short span of time like few months or years. Hence there is a possibility of complete www.ijsea.com removal or alteration. Srinivasalu (2009) made frequent visits and observed the consequences of alterations of $24^{\text {th }}$ Dec 2004 tsunami of the same study area and he found that there were three different layers occurred from top to bottom. The upper layer he observed that cross laminations with wavy patterns, middle with cross laminations and the lower with lateral laminated sheets. There were minimum two layers observed at all the places of the study area having fining upwards and thinning landwards.

The lack of knowledge in differentiating a tsunami from a storm deposit led to the controversy in previous publications (Bryant et al., 1992). Goff et al. (2004) published the paper in Marine Geology that differentiate the 2002 storm deposits and $15^{\text {th }}$ century tsunami deposits of New Zealand based on textural characteristics. Textural parameters of river sediments vary from the beach sediments (Rajamanickam and Muthukrishnan 1995). Fine sediments present in tsunami deposits vary from mud and fine sands of lakes and bays. Predominance of muddy sand found in the west coast of Indian lakes and bays due to ebbing of tidal waters constantly winnowed the finer particles (Reji Srinivasan and Kurian Sajan 2010). Medium sand with mesokurtic are supplied by river and reworked by marine currents when they exposed to wave action (Anfuso 1999). Further he illustrated that the grains less than 0 phi are transported by suspension and greater than that are by traction.

Prehistoric tsunami have also been identified by the sand sheets found in coastal low lands of Scotland (Dawson et.al., 1988),Pacific Northwest (Atwar and Moore, 1992, Bension et.al., 1997), New zealand (Clague-Goff and Goff, 1999), the Mediterranean (Dominey-Howes et.al. 1999), the Pacific coast of North America (Clague et.al. 2000), Hawaii (Moore, 2000), Kamchatka (Pinegina et.al., 2003), Japan (Nanayama et. al., 2003), Chile (Cisternas et. al., 2005) and Thailand (Jankaew et. al., 2008) had markers of paleotsunami especially enriched with high concentration of heavy minerals. These were observed in the trench walls of the study area also.

\section{Study Area}

The study area lies within the limit of Pumpuhar to Chandrapadi of east coast of central part of TamilNadu, India. The five trenches made at Manickabangu (MKB-T $79^{\circ}$ 
51.40E Long. and $11^{\circ} 03.76 \mathrm{~N}$ Lat.), Chandrapadi (CHP-T $79^{\circ}$ 51.38E Long. $11^{\circ} 00.24 \mathrm{~N}$ Lat.), Pillai Perumal Nallur (PPN-T $11^{\circ} 04.79 \mathrm{E}$ Long. $79^{\circ} 51.47 \mathrm{~N}$ Lat.), Vanagiri (VAG$\mathrm{T} 79^{\circ}$ 51.51E Long. $11^{\circ} 07.18 \mathrm{~N}$ Lat.) and Chinnamedu (CMD-T $79^{\circ}$ 51.54E Long. $11^{\circ} 05.89 \mathrm{~N}$ Lat.) (Fig-1). The station interval was fixed based on the recent tsunami worst affected places and with the knowledge of the shoreline changes like erosion and accretion. The beach was seen with varying width from narrow to wide and rich in heavy mineral on the surface at some places and others were lighter in tone. Beach slope was very gentle and low angle ranging from $3^{\circ}$ to $5^{\circ}$. The northern part comprised of deltaic plain and estuary of the Cauveri river and the southern parts also have the estuaries of distributaries of the same river. Chinnankudi near Chinnamedu region is discharged with Ambanar River.

\section{Methodology}

The five sample locations were marked with GPS and the sites were suitably selected near base of seaward side of beach ridges where the preservation of paleo-tsunami signatures were believed to be more without much alteration. The trench were made perpendicular to the ridges with $3 \mathrm{ft}$ width, $5 \mathrm{ft}$ length and depth upto water table. The layers were photographed (Fig -2) and the samplings were made from top to bottom with varying interval as per noticeable changes were observed.

The samples collected were washed with Distilled water, Hydrogen Ferroxide, HCL and $\mathrm{HNO}_{3}$ with Tin chloride to remove soluble substances, Organic content, carbonates and iron coatings. During the process drying and weighing was made at every stage to compute the weight loss. After drying, sieving has been done by using ASTM sieve mesh with quarter phi interval. The weights were recorded to find various statistical parameters like Mean, Median, Mode, $1^{\text {st }}$ percentile, Sorting, Skewness and Kurotsis.

\section{Results and Discussion}

\subsection{Field observations}

When the trenches were made the noticeable variation in lithology observed as in figure 2 were recorded and the dark patches seen represent the fine sediments of heavy mineral rich layer. Bottom of the layers showed the scoring that is undulated mark observed notice that the erosion occurred during tsunami wash. Dark layer itself consists of thin bands of laminations with varying thickness. At some places the lateritised layers were observed that indicates the area underwent long exposure to weathering for a long period of time without deposition.

\subsection{Frequency Distribution}

Frequency curves that plot grain size classes on the $\mathrm{x}$-axis, and proportion of grain size class on the $y$-axis Fig- 3 can be used to glean general information about the grain size distribution of the sediment population in the individual sediment. The most abundant class (mode) of the sample can be described from peaks whereas sorting in the sample is generally expressed by the spread of the data along $\mathrm{x}$-axis, it indicates transport process. Skewness and kurtosis of a sediment population have been used as indicators of sorting. Skewness compares the sorting in the coarse and finer grained halves of a sediment sample. In normal distribution mean, median and mode of the population coincide but for skewed they do not. Kurtosis or peakedness compares the sorting in the central portion of the grain size distribution with sorting in the tails (ends) of the distribution.

Chandrapadi sediments shows higher fine populations in 25$30,30-35$ and $45-51 \mathrm{~cm}$ depth, whereas other samples from this core shows coarser sand as a major constituent (Fig -3a). Manickabungu sediments that don't show many variations but the samples obtained from $0-20,52-61$ and $77-87 \mathrm{~cm}$ are having more fine populations than that of coarse but all the other samples obtained from this core having coarser populations (Fig -3b).

Cinnamedu trench samples exhibits some distinct variations in abundance of fine populations at the depth of $0-15,28-33,46-$ 51 and 51-54 $\mathrm{cm}$ (Fig $-3 \mathrm{c})$.

Pillaiperumanallur Trench has not shown much variation in their populations except $0-15$.This $0-15$ alone more fine grained than other samples (Fig -3d).

Vanagiri Trench $0-10$ and $10-20 \mathrm{~cm}$ depth of samples are having more fine populations than that of other samples, but at the depth of $58-60 \mathrm{~cm}$ still fine sediments present (Fig -3e).

\subsection{Textural Parameters}

The grainsize populations having different populations are due to the transportation by rolling, suspension and saltation (Inman, 1949). Textural parameters of sediments namely Mean, Standard deviation (Sorting), Skewness and Kurtosis were used to decipher the depositional environments of sediments (Folk and Ward, 1957; Mason and Folk, 1958; Friedman, 1961, 1967; Visher, 1969).

All the sediments obtain from all the locations exhibits only the Polymodal in nature

The mean grain size of Chandrapadi trench shows medium sand at $0-10(1.7013 \phi), 10-20(1.6333 \phi), 35-45(1.7622 \phi)$ and $45-51 \mathrm{~cm}(1.7622 \phi)$. All the others are fine sand (Table $-1 \mathrm{a})$. From the frequency curve one can ascribed that from $0-20 \mathrm{~cm}$, this having mixed populations of coarse as well as fine (table1a). All the samples are showing very well sorted nature and very fine skewed. Except at $0-20$ and $30-51 \mathrm{~cm}$ almost all are mesokurtic. These two are leptokurtic in nature (Fig -4a).

$0-20(3.0261 \phi)$ and $77-93 \mathrm{~cm}(3.3402$ to $3.2794 \phi)$ depth samples of Manickabungu Trench having very fine sand, but all the others fall under fine sand category.0-20, $87-90 \mathrm{~cm}$ depth samples showing very fine skewness, that means either addition of fine are removal of coarse played the role (Table 1b). $68-77 \mathrm{~cm}$ sample shows symmetrical skewness others are coarse skewed that means addition of coarse particles are more at $20-35 \mathrm{~cm}$ results platykurtic and all the remaining samples are mesokurtic except leptokurtic at $87-93 \mathrm{~cm}$ (Fig $4 \mathrm{~b})$.

$38-40(1.9805 \phi)$ and $44-46 \mathrm{~cm}(1.8027 \phi)$ depth samples of Cinnamedu Trench shows that they are of medium sand, all the other are fine sand (Table $-1 \mathrm{c})$. All are very well sorted and very fine skewed. The samples at the depth of 20-24 is coarse skewed, $33-44 \mathrm{~cm}$ are coarse skewed. The samples obtained from $15-20,24-28 \mathrm{~cm}$ and $46-51 \mathrm{~cm}$ are platykurtic and the remaining are mesokurtic in nature (Fig $-4 \mathrm{c}$ ).

At Vanagiri Trench all the samples obtain at various depth, showing very well sorted very fine skewed, fine sand but only the character forth moment kurtosis noticed at 0-10,30-35 and $45-70 \mathrm{~cm}$ are mesokurtic whereas $10-30,35-45$ and $70-85 \mathrm{~cm}$ are platykurtic and $85-90 \mathrm{~cm}$ alone leptokurtic in nature (Fig 4d) (Table -1d).

Samples obtained at various depth of Pillaiperumanallur Trench shows that they are all very well sorted fine sand having very fine skewed nature (Table -1e). Sample from 0$30 \mathrm{~cm}$ depth is fine skewed $30-40$ and $40-43 \mathrm{~cm}$ are symmetrically skewed in nature. 5-10, 15-20, 30-43 and 43-50 
are mesokurtic in nature whereas remaining samples are platykurtic (Fig -4e).

The phi mean size of the $24^{\text {th }}$ Dec 2005 sediments varied from 0.830 to $3.153 \phi$ and $65 \%$ fell in the fine sand category and the rest in medium sand category. The sorting of the sediments were vary from 0.463 to $0.717 \phi$ that is well sorted to moderately well sorted. The symmetry of the sediments were vary from -0.159 to 1.143 that is from strongly fine skewed to coarse skewed (Singarasubramanian, et.al 2006). The fine skewed implied that the introduction fine sediments or removal of coarser sediments (Friedman, 1961). The fourth moment kurtosis of the sediments varied from 0.871 to 1.949 and $75 \%$ fell under leptokurtic nature (Singarasubramanian, et.al 2006).

\subsection{Bivariate plots}

A wide variety of bivariate plots using any two parameters of the grainsize analysis were applied for the interpretation (Friedman 1967, Tanner 1991).

\subsubsection{Visher's Diagram}

Log-Phi graphs plotted on probability paper have commonly been used in sediment grain size analysis (Sengupta et al. 1991). Many papers adopted this technique (Inman 1949, Spencer 1963) cumulating in the summary by Visher (1969). Visher (1969) described how the distribution of grains in this siliclastic rock or unconsolidated sediment sample may be related to their transport process and environment of deposition. The segments on to probability Plots have commonly been described as a coarse and fine how together with central segment (Tanner 1991) indicating different transport process and the same have been used as fingerprints for recognizing depositional environment in ancient sedimentary rocks (Visher 1969). He found that three segments - line A from $0 \varnothing$ to $2 \varnothing$ transported by Traction, line B from $2 \varnothing$ to $4 \varnothing$ transported by Saltation and line C from $4 \varnothing$ to $8 \varnothing$ transported by suspension. Beach swash and backwash have two saltation populations.

Visher diagram of Chandrapadi Trench samples shows that 010 and $10-20 \mathrm{~cm}$ are transported by means of traction and also little bit extent $35-51 \mathrm{~cm}$ samples also (Fig 5a). The samples from $90-115 \mathrm{~cm}$ and $125-150 \mathrm{~cm}$ are all transported by means of suspension, all the remaining sample transported by means of saltation either by swash or backwash.

Cinnamedu Trench samples of $38-40$ and $44-46 \mathrm{~cm}$ are transported by means of traction and samples obtained from $51-60 \mathrm{~cm}$ are transported by means of suspension and all the remaining samples shows that they were all transported by means of saltation (Fig $5 b$ ).

Manickabungu trench samples shows that most of the samples are transported by saltation except $0-20 \mathrm{~cm}$ and above $77 \mathrm{~cm}$ are by suspension (Fig $5 \mathrm{c}$ ).

Pillaiperumanallur Trench samples shows that the samples obtained at the depth of $0-5,15-20$ and $20-30 \mathrm{~cm}$ are transported by traction whereas all the remaining samples transported by means of saltation (Fig 5d).

Vanagiri Trench samples obtained at the depth of 0-10 and $71-80 \mathrm{~cm}$ are transported by means of traction and also the saltation population is very less but the remaining samples shows that they are all transported by means of beach environment (Fig 5e).

\subsubsection{CM pattern}

The CM pattern (Passega 1964) is plotted by using $1^{\text {st }}$ percentile Vs Median in log probability exhibits the study area sediments were transported either by graded suspension with rolling (Q-R) or by uniform suspension (R-S). Few samples exhibit bottom suspension and rolling (P-Q). Almost all fall between $C=80$ to 400 microns and $M=80$ to 200 microns. The position of the dividing line 300 microns away from the normal pattern suggests the distribution of finer sediments. Absences of sediment population in $\mathrm{N}-\mathrm{O}$ segment reveals that there is no much fluvial influence but few samples fall in P-Q segment represents the little bit river contribution is there. Abundance of population fall in Q-R illustrates that almost all were transported by means of graded suspension. Very few samples only deviated towards R-S segment that they are all transported by means of uniform suspension.

Sediments obtained from Chandrapadi Trench source that the samples from $0-10,10-20$, and $35-51 \mathrm{~cm}$ are all transported by means of graded suspension with rolling. The samples obtained at the depth of $90-150 \mathrm{~cm}$ are transported by means of uniform suspension. Remaining samples lie in between graded and uniform suspension of P-Q segment. The samples obtained at the depth of $40-77 \mathrm{~cm}$ are all transported by means of graded suspension with rolling, and the remaining shows that they are all transported by means of uniform suspension (Fig 6).

At the same time Manickabungu Trench samples beyond the depth of $40 \mathrm{~cm}$ are having coarser particles more than that of fine.

Samples obtained from Cinnamedu Trench reveals that at the depth 51-60 cm grains transported by means of uniform suspension and the others transported by graded suspension with rolling.

Vanagiri Trench samples shows that the samples from 010.20-35 and 85-90 are transported by means of graded suspension with rolling and all the other by means of uniform suspension.

Pillaiperumanallur Trench obtained at the depth of $5-10 \mathrm{~cm}$, $10-15 \mathrm{~cm}$ are transported by means of uniform suspension and all the others transported by means of graded suspension with rolling.

\subsection{Cluster Analysis}

Cluster analysis is an exploratory data analysis tool which aims at sorting different objects into groups in a way that the degree of association between two objects is maximal if they belong to the same group and minimal otherwise. It can be used to discover structures in data without providing an explanation/interpretation and why they exist. As a result one can link more and more objects together and aggregate larger and larger clusters of increasingly dissimilar elements. Finally, in the last step, all objects are joined together. In these plots, the horizontal axis denotes the linkage distance.

Hierarchical cluster Chandrapadi Trench reveals that there is a maximum difference between few samples with other, the samples obtained at $0-20 \mathrm{~cm}$ as one group and $30-51 \mathrm{~cm}$ as another group behaves distinct from all the other (Fig 7a).

The cluster analysis of Manickabungu Trench reveals that the samples of $20-35,68-77 \mathrm{~cm}$ and above $93 \mathrm{~cm}$ are distinct than that of others. Another group encompasses 0-20 and 77-93 (Fig 7b).

Cinnamedu Trench cluster analysis reveals that 15-20, 24-28 and $46-51 \mathrm{~cm}$ as different group, $28-33 \mathrm{~cm}$ as distinct and $51-$ $60 \mathrm{~cm}$ as a different group. All the remaining behaves as same (Fig 7c).

The cluster analysis of Pillaiperumanallur Trench reveals that 5-10 and $48-50 \mathrm{~cm}$ as different group and all the remaining comes under one group (Fig 7d).

When Vanagiri Trench cluster analysis concerned $30-35 \mathrm{~cm}$ and $85-90 \mathrm{~cm}$ are behaving different than that of remaining all (Fig 7e). 


\section{Conclusion}

The areas like Vanagiri (0--20, 30-35 and 85-90), Chinnamedu (0-15, 28-34 and 51-54) having three evidences of tsunami event including the recent tsunami occurred on $26^{\text {th }}$ of December 2004 whereas Manickabangu (0-20 and 52-61) and Pillaiperumanallur (0-15 and 30-43) shows two signatures but at the same time Chandrapadi (10-30) location having only one at the top and the remaining two are below the hard lateritised layers (85-90). This has been suspected that the coast might have been undergone a long period of exposure for weathering that is why they may not be comparable with that of other locations.

The area undergoes continuous erosion from 1970 to 2000 and little bit accretion upto 2008 was noticed by means of frequent survey made in these areas. When erosion compared with the deposition the amount of accretion is very meager. This may be one of the reasons for obliteration of tsunami signatures at depths or they may be reworked by means of wave action or altered by other natural agents (Srinivasalu 2009). Further investigation by using marker species of forams or heavy mineral studies will reveal the Paleo-tsunami signatures in detail. The exact time period of tsunami occurrence can be identified by means of OSL $\mathrm{C}^{14}$ dating.

\section{Acknowledgments}

Author sincerely acknowledges Prof.Dr.G.VictorRajamanickam for his valuable guidance in the Paleotsunami study. He also thanks to the co-author who provide valuable guidance through his wonderful experience in the applied geology field. And also he thanks Dr.S.K.Chaturvedi, SASTRA University cooperated in the research for providing necessary infrastructure facilities for the research. The author acknowledges the co-workers of the same study Mr.R.VijayAnand, Neelakandan, and R.Mahesh..

\section{References}

[1] Anfuso, G., Achab, M., Cultrone, G., lopez-Aguayo, F., (1999). Utility of heavy minerals distribution and granulometric analyses in the study of coastal dynamics: Application to the littoral between Sanlucar de barrameda and Rota (Cadiz, southwest Iberian Peninsula), Bol. Inst. Esp.Oceanogr. 15 (1-4), PP. 243-250.

[2] Atwar, B.F., 2007. Hunting for ancient tsunamis in the tropics in $4^{\text {th }}$ Annual MeetingBangkok, Asia Oceania Geosciences Society, SE21-A0008, 241.

[3] Barbara, K., Whealan. F., and belly-Brock. J., 2000. Tsunami deposits at Queen's beach, Oahu, Hawaii-initial results and wave modeling. Science of tsunami Hazards. V.22; No.1. PP. 23-43.

[4] Benson, B.E., Grimm. K.A., Clague, J.J., 1997. Tsunami deposits beneath tidal marshes on northwestern Vancouver Island, British Columbia Quarternary Research, 48, PP.192-204.

[5] Briyant, E.A., Young. R.W., Price, D.M., 1992. Evidence of tsunami sedimentation on the southeastern coast of Australia: Journal of Geology, PP.100, 753-765.

[6] Chague-Goff, C., and R.Goff., 1999. Geochemical and Sedimentological signature of catastrophic seawater inundations (Tsunami), New Zealand, Quaternary Australia, 17. PP 38-48.

[7] Cisternas, M., Atwar,B.F., Torrejon,F., Sawai,Y., Machuea,G., Lagos,M., Eipert,A., Youlton, C., Salgado, I., Kamataki,T., Shishikura,M., Rajendran,C.P., Malik,
J.K., Rizal,Y., Husni,M., 2005, Predecessors of the grant 1960 Chile earthquake: Nature, PP.437, 404-407. et. Al., 2005.

[8] Clague, JJ., P.T.Bohnwsky and I.Hutchinson 2000. A review of geological records of large tsunamis at Vancouver Island, British Columbia and implications for hazard. Quarternary Sci. Rev. 19. PP 849-863.Dawson, A.G., D.Longwand, D.E.Smith (1988): The Storegga slides: evidence from eastern Scotland for a possible tsunami. Marine Geology. V.82. PP.271-276.

[9] Dzulynski,S., 1966. Sedimentary structures resulting from convection-like pattern of motion. Roez. Polskie Towarzystwo Geology PP.36, 3-21.

[10] Folk, R.L. and Ward.W.C., 1957. Brazos River Bar: a study in the significance of grain size parameter. Journal of Sedimentary Petrology, V. 27. PP.3-26.

[11] Friedman, G.M., 1961. Distribution between (sic) dune, beach, and river sands from their textural characteristics, Journal of Sedimentary Petrology. V.31, PP.514-529.

[12] Friedman, G.M., 1967, Dynamic processes and statistical parameters compared for size frequency distribution of beach (sic) and river sands. Journal of Sedimentary Petrology.V. 37, PP.327-354.

[13] Goff, J., McFadgen, B.G., Chague-Goff, C., 2004. Sedimentary differences between the 2002.Easter storm and the $15^{\text {th }}$-century Okoropunga tsunami, southeastern North Island, NewZealand: Marine Geology, 204, 235250.

[14] Inman, D.1., 1949. Searching sediments in the light fluid mechanics, Journal of Sedimentary Petrology V.19, PP. 51-70.

[15] Jankaew, K., Atwar, B.F., Sawai, Y., Choowong, M., Charoentitirat, T., Martim, M.E., Prendergast,A., 2008, Medieval forewarning of the 2004 .Indian Ocean tsunami in Thailand: Nature,V. 455, PP.1228-1231.

[16] Mason, C.C., and Folk, R.L., (1958) Differentiation of beach dune and Aeolian flat environment by size analysis, Mustang Island, Trxas. Journal of Sedimentary Petrology V.28. PP.211-226.

[17] Moore, A.L., 2000. Landward fining in on shore gravel as evidence for a late Pleistocene tsunami on Molokai, Hawaii: Geology, PP.28, 247-250.

[18] Nanayama, F., Satake, K., Furukawa, R., Shimokawa,K., Atwar, B.F., Shigeno, K., Yamaki, S., 2003. Unusually large earthquakes inferred from tsunami deposits along the Kuril trench: Nature, PP.424, 660-663.

[19] Passega , R., 1957,Texture as a characteristic of clastic deposition ,American Association of petroleum Geologists Bulletin, V.41, PPS. 1952-1984.

[20] Pinegina, T.K., Bourgeois. J., Bazanova, L.I., Melekestev,I.V., Braitseva,O.A., 2003. A millennialscale record of Holocene tsunamis on the Kronotskiy Bay coast, Kamachatka, Russia, Quaternary Research, PP.59, 36-47.

[21] Rajamanickam, G.V., and Muthukrishnan, N., 1995. Grain size distribution in the Gadilam river basin, northern TamilNadu, Journal of Indian Association Sedimentology., V.14. PP. 55-66. 
[22] Rajamanickam , G.V., and Prithviraj , M., 2006. Great Indian Ocean tsunami: Perspective in $26^{\text {th }}$ Dec. 2004 tsunami causes, effects. Remedial measures, pre and post tsunami disaster management a geoscientific perspective and Editor - Rajamanickam , G.V., Subramaniyam, B.R.,

[23] Rajendran, C.P., Rajendran, K., Machado, T., Satyamurthy, t., Aravazhi, P., jaiswal, M., 2006. Evidence of ancient sea surges at the Mamallapuram coast of India and implications for previous Indian Ocean tsunami events. Current science, V.91/9, PP. 1242 $-1247$.

[24] Reji Srinivasan and Kurian Sajan, 2010. Significance of textural analysis in the sediments of kayankulam lake, southwest coast of India, Indian Journal of Marine Sciences V.39 (1), March 2010. PP.292-99.

[25] Sengupta, S., Ghosh, J.K., and Mazumder , B.S., 1991 , Experimental - theoretical approach to interpretation of grain size frequency distributions, in Syvitski, J.P.M., editor, Principles, Methods and Application of Particle Size Analysis, Cambridge, Cambridge University Press, PP. 368.

[26] Shanmugam, G., 2006. The Tsunamite Problem. Journal of Sedimentary research 76/5 PP.718-730.

[27] Singarasubramanian, S.R., Mukesh, M.V., Manoharan, K., Murugan, S., Bakkiaraj, D., and Johnpeter, A., 2006. Sediment Charecteristics of the M-9 Tsunami event between Rameswaram and Thoothukkudi, Gulf of Mannar, Southeast coast of India, Science of tsunami Hazards, V.25, no.3, PP.160-171.

[28] Spencer, D.W., 1963. The interpretation of grain size distribution curves of clastic sediments, Journal of Sedimentary Petrology v. 33, PP. 180-190.

[29] Srinivasalu, S, RajeswaraRao, N., Thangadurai, N., Jonathan, M.P., Roy, P.D., RamMohan, V., Saravanan, P., 2009. Characteristics of 2004 tsunami deposits of the northern TamilNadu Coast, Southeastern India, Boletin de la Sociedad Geologica Mexicana, V61, No.1, PP.111118.

[30] Tanner, W.F., 1991. Suite Statistics: The hydrodynamic evolution of the sediment pool PP. 225-236 in Syvitski, J.P.M., editor, Principles, Methods and Application of Particle size analysis, Cambridge, Cambridge University Press, PP.368.

[31] Visher, G.S., 1969. Grain size distribution depositional processes, journal of sedimentary petrology, V.39, PP.1074-1106. 
International Journal of Science and Engineering Applications

Volume 1 Issue 1, 2012

Table - 1 a. Grain size parameters of Chandrapadi Trench (CHP-T)

\begin{tabular}{|c|c|c|c|c|c|c|c|}
\hline Depth & $\begin{array}{c}\text { Mean } \\
\phi\end{array}$ & $\begin{array}{c}\text { Sorting } \\
\phi\end{array}$ & Skewness & Kurtosis & $1^{\text {st }}$ percentile mm & $50^{\text {th }}$ percentile $\mathrm{mm}$ & Remarks \\
\hline $0-10$ & 1.7013 & 0.5992 & 1.3187 & 5.8615 & 151.3 & 306.2 & $\begin{array}{l}\text { Medium sand, Very well } \\
\text { sorted, Very fine skewed, } \\
\text { Leptokurtic. }\end{array}$ \\
\hline $10-20$ & 1.633 & 0.6376 & 1.1080 & 5.3416 & 155.5 & 309.9 & $\begin{array}{l}\text { Medium sand,Very well } \\
\text { sorted, Very fine skewed, } \\
\text { Leptokurtic }\end{array}$ \\
\hline $20-25$ & 2.1785 & 0.6622 & 0.2897 & 3.4472 & 125.1 & 233.6 & $\begin{array}{l}\text { Fine sand, Very well sorted, } \\
\text { Very fine skewed, Mesokurtic }\end{array}$ \\
\hline $25-30$ & 2.1785 & 0.6622 & 0.2897 & 3.4472 & 112.6 & 212.3 & $\begin{array}{l}\text { Fine sand, Very well sorted, } \\
\text { Very fine skewed, Mesokurtic }\end{array}$ \\
\hline $30-35$ & 2.0004 & 0.5834 & 0.8504 & 4.5765 & 128.2 & 227.5 & $\begin{array}{l}\text { Fine sand, Very well sorted, } \\
\text { Very fine skewed, Leptokurtic }\end{array}$ \\
\hline $35-45$ & 1.7622 & 0.6480 & 0.8339 & 4.4728 & 141.6 & 247.3 & $\begin{array}{c}\text { Medium sand, Very well } \\
\text { sorted, Very fine skewed, } \\
\text { Leptokurtic }\end{array}$ \\
\hline $45-51$ & 1.7622 & 0.6480 & 0.8339 & 4.4728 & 141.6 & 247.3 & $\begin{array}{l}\text { Medium sand, Very well } \\
\text { sorted, Very fine skewed, } \\
\text { Leptokurtic }\end{array}$ \\
\hline $51-60$ & 2.1438 & 0.6775 & 0.3543 & 3.1121 & 111.3 & 217.0 & $\begin{array}{l}\text { Fine sand,Very well sorted, } \\
\text { Very fine skewed, Mesokurtic }\end{array}$ \\
\hline $60-70$ & 2.2044 & 0.6891 & 0.3939 & 2.9720 & 109.2 & 213.7 & $\begin{array}{l}\text { Fine sand,Very well sorted, } \\
\text { Very fine skewed, Mesokurtic }\end{array}$ \\
\hline $70-85$ & 2.2410 & 0.6428 & 0.2275 & 2.5912 & 108.1 & 175.5 & $\begin{array}{l}\text { Fine sand,Very well sorted, } \\
\text { Very fine skewed, Leptokurtic }\end{array}$ \\
\hline $85-90$ & 2.5340 & 0.6532 & 0.0985 & 2.5905 & 106.1 & 170.7 & $\begin{array}{l}\text { Fine sand,Very well sorted, } \\
\text { Very fine skewed, Mesokurtic }\end{array}$ \\
\hline $90-100$ & 2.6522 & 0.6499 & 0.0010 & 2.4977 & 85.8 & 158.4 & $\begin{array}{l}\text { Fine sand,Very well sorted, } \\
\text { Very fine skewed, Mesokurtic }\end{array}$ \\
\hline $100-110$ & 2.6211 & 0.6393 & 0.0009 & 2.5246 & 87.6 & 160.2 & $\begin{array}{l}\text { Fine sand,Very well sorted, } \\
\text { Very fine skewed, Mesokurtic }\end{array}$ \\
\hline $110-115$ & 2.4975 & 0.6835 & 0.0242 & 2.5704 & 89.5 & 174.2 & $\begin{array}{l}\text { Fine sand,Very well sorted, } \\
\text { Very fine skewed, Mesokurtic }\end{array}$ \\
\hline $115-125$ & 2.4199 & 0.6496 & 0.2678 & 2.5796 & 109.2 & 215.1 & $\begin{array}{l}\text { Fine sand,Very well sorted, } \\
\text { Very fine skewed, Mesokurtic }\end{array}$ \\
\hline $125-130$ & 2.6277 & 0.6884 & -0.3191 & 2.9505 & 85.8 & 153.0 & $\begin{array}{l}\text { Fine sand,Very well sorted, } \\
\text { Very fine skewed, Mesokurtic }\end{array}$ \\
\hline $130-140$ & 2.6340 & 0.6958 & -0.2710 & 2.8417 & 85.2 & 157.4 & $\begin{array}{l}\text { Fine sand,Very well sorted, } \\
\text { Very fine skewed, Mesokurtic }\end{array}$ \\
\hline $140-150$ & 2.6003 & 0.7118 & -0.3033 & 3.0201 & 86.3 & 160.6 & $\begin{array}{l}\text { Fine sand,Very well sorted, } \\
\text { Very fine skewed, Mesokurtic }\end{array}$ \\
\hline $150-160$ & 2.4987 & 0.6857 & -0.0962 & 2.8884 & 106.7 & 172.2 & $\begin{array}{l}\text { Fine sand, Very well sorted, } \\
\text { Very fine skewed, Mesokurtic }\end{array}$ \\
\hline $160-170$ & 2.2234 & 0.6221 & 0.3094 & 2.7905 & 121.1 & 227.6 & $\begin{array}{l}\text { Fine sand, Very well sorted, } \\
\text { Very fine skewed, Mesokurtic }\end{array}$ \\
\hline
\end{tabular}

Table - 1 b. Grain size parameters of Manickabangu Trench (MKB-T)

\begin{tabular}{|c|c|c|c|c|c|c|c|}
\hline Depth & $\begin{array}{c}\text { Mean } \\
\phi\end{array}$ & $\begin{array}{c}\text { Sorting } \\
\phi\end{array}$ & Skewness & Kurtosis & $1^{\text {st }}$ percentile mm & $50^{\text {th }}$ percentile mm & Remarks \\
\hline $0-20$ & 3.0261 & 0.4968 & -0.3802 & 3.5509 & 80.7 & 121.9 & $\begin{array}{c}\text { Very fine sand,Very well sorted, } \\
\text { Very fine skewed, Mesokurtic } \\
\text { Fine sand ,Very well sorted, Fine } \\
\text { skewed,Platykurtic }\end{array}$ \\
$35-40$ & 2.2816 & 0.5995 & 0.4597 & 2.7855 & 119.0 & 92.9 & 172.3 \\
$\begin{array}{c}\text { Fine sand ,Very well sorted, Coarse } \\
\text { skewed, Mesokurtic }\end{array}$
\end{tabular}


International Journal of Science and Engineering Applications

Volume 1 Issue 1, 2012

\begin{tabular}{|c|c|c|c|c|c|c|c|}
\hline $40-47$ & 2.1632 & 0.6299 & 0.6180 & 2.9932 & 121.6 & 235.6 & $\begin{array}{c}\text { Fine sand,Very well sorted, Coarse } \\
\text { skewed, Mesokurtic }\end{array}$ \\
\hline $47-52$ & 2.1582 & 0.5459 & 0.7164 & 3.2643 & 133.6 & 234.8 & $\begin{array}{c}\text { Fine sand,Very well sorted, Coarse } \\
\text { skewed, Mesokurtic }\end{array}$ \\
\hline $52-58$ & 2.2986 & 0.5978 & 0.5246 & 2.9139 & 118.5 & 223.6 & $\begin{array}{c}\text { Fine sand,Very well sorted, Coarse } \\
\text { skewed, Mesokurtic }\end{array}$ \\
\hline $58-61$ & 2.4448 & 0.5821 & 0.7062 & 3.1019 & 125.5 & 232.7 & $\begin{array}{c}\text { Fine sand,Very well sorted, Coarse } \\
\text { skewed, Mesokurtic }\end{array}$ \\
\hline $61-68$ & 2.3624 & 0.5920 & 0.6456 & 3.1413 & 132.1 & 238.7 & $\begin{array}{c}\text { Fine sand,Very well sorted, Coarse } \\
\text { skewed, Mesokurtic }\end{array}$ \\
\hline $68-77$ & 2.6957 & 0.5622 & 0.3516 & 2.7234 & 113.2 & 212.0 & $\begin{array}{c}\text { Fine sand ,Very well sorted, } \\
\text { Symmetrical,Mesokurtic }\end{array}$ \\
\hline $77-87$ & 3.3402 & 0.4410 & -0.5579 & 4.1658 & 80.1 & 118.3 & $\begin{array}{c}\text { Very fine sand,Very well } \\
\text { sorted,Symmetrical,Leptokurtic }\end{array}$ \\
\hline $87-90$ & 3.2794 & 0.4213 & -0.2146 & 3.7822 & 82.3 & 122.7 & $\begin{array}{l}\text { Very fine sand ,Very well sorted, } \\
\text { Very fine skewed, Leptokurtic }\end{array}$ \\
\hline $90-93$ & 3.2875 & 0.4443 & -0.3994 & 3.8604 & 81.5 & 121.4 & $\begin{array}{l}\text { Very fine sand ,Very well sorted, } \\
\text { Very fine skewed, Leptokurtic }\end{array}$ \\
\hline $\begin{array}{c}\text { Above } \\
93\end{array}$ & 3.1036 & 0.5656 & -0.0696 & 2.7168 & 82.3 & 139.7 & $\begin{array}{l}\text { Very fine sand,Very well sorted, } \\
\text { Very fine skewed, Mesokurtic }\end{array}$ \\
\hline
\end{tabular}

\begin{tabular}{|c|c|c|c|c|c|c|c|}
\hline Depth & $\begin{array}{c}\text { Mean } \\
\phi\end{array}$ & $\begin{array}{c}\text { Sorting } \\
\phi\end{array}$ & Skewness & Kurtosis & $1^{\text {st }}$ percentile & $50^{\text {th }}$ percentile & Remarks \\
\hline $15-20$ & 2.4786 & 0.5855 & 0.2648 & 2.5523 & 110.8 & 176.6 & $\begin{array}{c}\text { Fine sand,Very well sorted,Very fine } \\
\text { skewed,Platykurtic }\end{array}$ \\
\hline $20-24$ & 2.1271 & 0.5804 & 0.8457 & 3.3820 & 129.0 & 239.0 & $\begin{array}{c}\text { Fine sand,Very well sorted, coarse skewed, } \\
\text { Mesokurtic }\end{array}$ \\
\hline $24-28$ & 2.5149 & 0.6029 & 0.0690 & 2.3189 & 109.9 & 168.8 & $\begin{array}{l}\text { Fine sand,Very well sorted, Very fine } \\
\text { skewed,Platykurtic }\end{array}$ \\
\hline $28-33$ & 2.7830 & 0.5202 & -0.4958 & 3.3268 & 106.2 & 139.3 & $\begin{array}{l}\text { Fine sand,Very well sorted, Very fine skewed, } \\
\text { Mesokurtic }\end{array}$ \\
\hline $33-38$ & 2.1538 & 0.6229 & 0.7764 & 2.9810 & 121.0 & 238.2 & $\begin{array}{c}\text { Fine sand,Very well sorted, Coarse skewed, } \\
\text { Mesokurtic }\end{array}$ \\
\hline $38-40$ & 1.9805 & 0.6209 & 0.8164 & 3.1846 & 132.8 & 304.4 & $\begin{array}{c}\text { Medium sand,Very well sorted, Coarse skewed, } \\
\text { Mesokurtic }\end{array}$ \\
\hline $40-44$ & 2.0943 & 0.5769 & 0.6762 & 3.1563 & 132.7 & 240.3 & $\begin{array}{c}\text { Fine sand ,Very well sorted, Coarse skewed, } \\
\text { Mesokurtic }\end{array}$ \\
\hline $44-46$ & 1.8027 & 0.6338 & 0.6240 & 3.4576 & 153.7 & 316.0 & $\begin{array}{c}\text { Medium sand,Very well sorted, Coarse skewed, } \\
\text { Mesokurtic }\end{array}$ \\
\hline $46-51$ & 2.3502 & 0.6979 & 0.0469 & 2.3276 & 110.2 & 216.6 & $\begin{array}{c}\text { Fine sand ,Very well sorted, Very fine } \\
\text { skewed,Platykurtic }\end{array}$ \\
\hline $51-54$ & 2.6450 & 0.7549 & -0.4026 & 2.7042 & 84.1 & 150.6 & $\begin{array}{l}\text { Fine sand ,Very well sorted, fine } \\
\text { skewed,Mesokurtic }\end{array}$ \\
\hline $54-56$ & 2.6773 & 0.7229 & -0.3642 & 2.8313 & 83.7 & 148.3 & $\begin{array}{l}\text { Fine sand,Very well sorted, fine } \\
\text { skewed,Mesokurtic }\end{array}$ \\
\hline $56-60$ & 2.8317 & 0.6522 & -0.3035 & 2.8082 & 81.3 & 137.7 & $\begin{array}{l}\text { Fine sand, Very well sorted, fine } \\
\text { skewed,Mesokurtic }\end{array}$ \\
\hline
\end{tabular}

\begin{tabular}{|c|c|c|c|c|c|c|c|}
\hline Depth & $\begin{array}{c}\text { Mean } \\
\phi\end{array}$ & $\begin{array}{c}\text { Sorting } \\
\phi\end{array}$ & Skewness & Kurtosis & $1^{\text {st }}$ percentile & $50^{\text {th }}$ percentile & Remarks \\
\hline $0-10$ & 2.4119 & 0.6466 & 0.2486 & 2.6232 & 111.3 & 213.6 & $\begin{array}{c}\text { Fine sand,Very well sorted, Very fine skewed, } \\
\text { Mesokurtic }\end{array}$ \\
$20-25$ & 2.7184 & 0.6559 & 0.0593 & 2.5139 & 84.3 & 138.1 & $\begin{array}{c}\text { Fine sand,Very well sorted, Very fine } \\
\text { skewed,Platykurtic }\end{array}$ \\
$25-30$ & 2.5861 & 0.7363 & 0.1464 & 2.2363 & 85.3 & 171.8 & $\begin{array}{c}\text { Fine sand,Very well sorted, Very fine skewed, } \\
\text { Platyurtic }\end{array}$ \\
$30-35$ & 2.4851 & 0.5956 & 0.5904 & 3.3290 & 112.7 & 182.5 & $\begin{array}{c}\text { Fine sand,Very well sorted, Very fine skewed, } \\
\text { Platykurtic }\end{array}$ \\
& & 0.1945 & 2.4117 & 88.5 & $\begin{array}{c}\text { Fine sand,Very well sorted, Very fine skewed, } \\
\text { Mesokurtic }\end{array}$
\end{tabular}


International Journal of Science and Engineering Applications

Volume 1 Issue 1, 2012

\begin{tabular}{|c|c|c|c|c|c|c|c|}
$35-45$ & 2.6935 & 0.7364 & -0.0743 & 2.4214 & 83.0 & 153.8 & $\begin{array}{c}\text { Fine sand,Very well sorted, Very fine skewed, } \\
\text { Platykurtic }\end{array}$ \\
$45-51$ & 2.8326 & 0.6171 & -0.2329 & 2.8523 & 83.1 & 137.1 & $\begin{array}{c}\text { Fine sand,Very well sorted, Very fine skewed, } \\
\text { Mesokurtic }\end{array}$ \\
$51-60$ & 2.7102 & 0.6581 & 0.0384 & 2.5673 & 84.9 & 154.1 & $\begin{array}{c}\text { Fine sand,Very well sorted, Very fine skewed, } \\
\text { Mesokurtic }\end{array}$ \\
$60-70$ & 2.7713 & 0.6121 & -0.0919 & 2.8851 & 86.1 & 145.1 & $\begin{array}{c}\text { Fine sand,Very well sorted, Very fine skewed, } \\
\text { Mesokurtic }\end{array}$ \\
$70-85$ & 2.6673 & 0.7075 & -0.2143 & 2.4887 & 84.9 & 150.3 & $\begin{array}{c}\text { Fine sand,Very well sorted, Very fine skewed, } \\
\text { Platykurtic }\end{array}$ \\
$85-90$ & 2.8457 & 0.4609 & 0.0281 & 3.9795 & 106.4 & 140.1 & $\begin{array}{c}\text { Fine sand,Very well sorted, Very fine skewed, } \\
\text { Leptokurtic }\end{array}$ \\
\hline
\end{tabular}

Table - 1 e. Grain size parameters of Pillaiperumanallur Trench (PPN-T)

\begin{tabular}{|c|c|c|c|c|c|c|c|}
\hline Depth & $\begin{array}{c}\text { Mean } \\
\phi\end{array}$ & $\begin{array}{c}\text { Sorting } \\
\phi\end{array}$ & Skewness & Kurtosis & $1^{\text {st }}$ percentile & $50^{\text {th }}$ percentile & Remarks \\
\hline $0-5$ & 2.5454 & 0.6032 & 0.2323 & 2.4601 & 106.9 & 170.2 & $\begin{array}{c}\text { Fine sand, Very well sorted, Very fine } \\
\text { skewed,Platykurtic }\end{array}$ \\
\hline $5-10$ & 2.8202 & 0.6295 & -0.3562 & 2.7553 & 82.2 & 136.2 & $\begin{array}{c}\text { Fine sand, Very well sorted, Very fine } \\
\text { skewed,Mesokurtic }\end{array}$ \\
\hline $10-15$ & 2.6254 & 0.7048 & -0.1068 & 2.4664 & 85.1 & 158.4 & $\begin{array}{l}\text { Fine sand, Very well sorted, Very fine skewed, } \\
\text { Platykurtic }\end{array}$ \\
\hline $15-20$ & 2.5071 & 0.6507 & 0.0538 & 2.6807 & 107.4 & 170.1 & $\begin{array}{l}\text { Fine sand, Very well sorted, Very fine skewed, } \\
\text { Mesokurtic }\end{array}$ \\
\hline $20-30$ & 2.5157 & 0.6074 & 0.3577 & 2.5451 & 107.1 & 175.8 & $\begin{array}{c}\text { Fine sand, Very well sorted, Fine skewed, } \\
\text { Platykurtic }\end{array}$ \\
\hline $30-40$ & 2.6210 & 0.6603 & 0.1796 & 2.4262 & 86.0 & 163.6 & $\begin{array}{c}\text { Fine sand, Very well sorted, Symmmetrical, } \\
\text { Platykurtic }\end{array}$ \\
\hline $40-43$ & 2.5913 & 0.6581 & 0.1157 & 2.3657 & 87.4 & 164.9 & $\begin{array}{c}\text { Finesand,Very well } \\
\text { sorted,Symmmetrical,Platykurtic }\end{array}$ \\
\hline $43-48$ & 2.8097 & 0.5909 & -0.0679 & 2.6435 & 83.3 & 142.8 & $\begin{array}{l}\text { Fine sand,Very well sorted, Very fine skewed, } \\
\text { Mesokurtic }\end{array}$ \\
\hline $48-50$ & 2.9279 & 0.5815 & -0.2611 & 2.8581 & 80.7 & 130.2 & $\begin{array}{c}\text { Fine sand,Very well sorted, Very fine skewed, } \\
\text { Mesokurtic }\end{array}$ \\
\hline
\end{tabular}




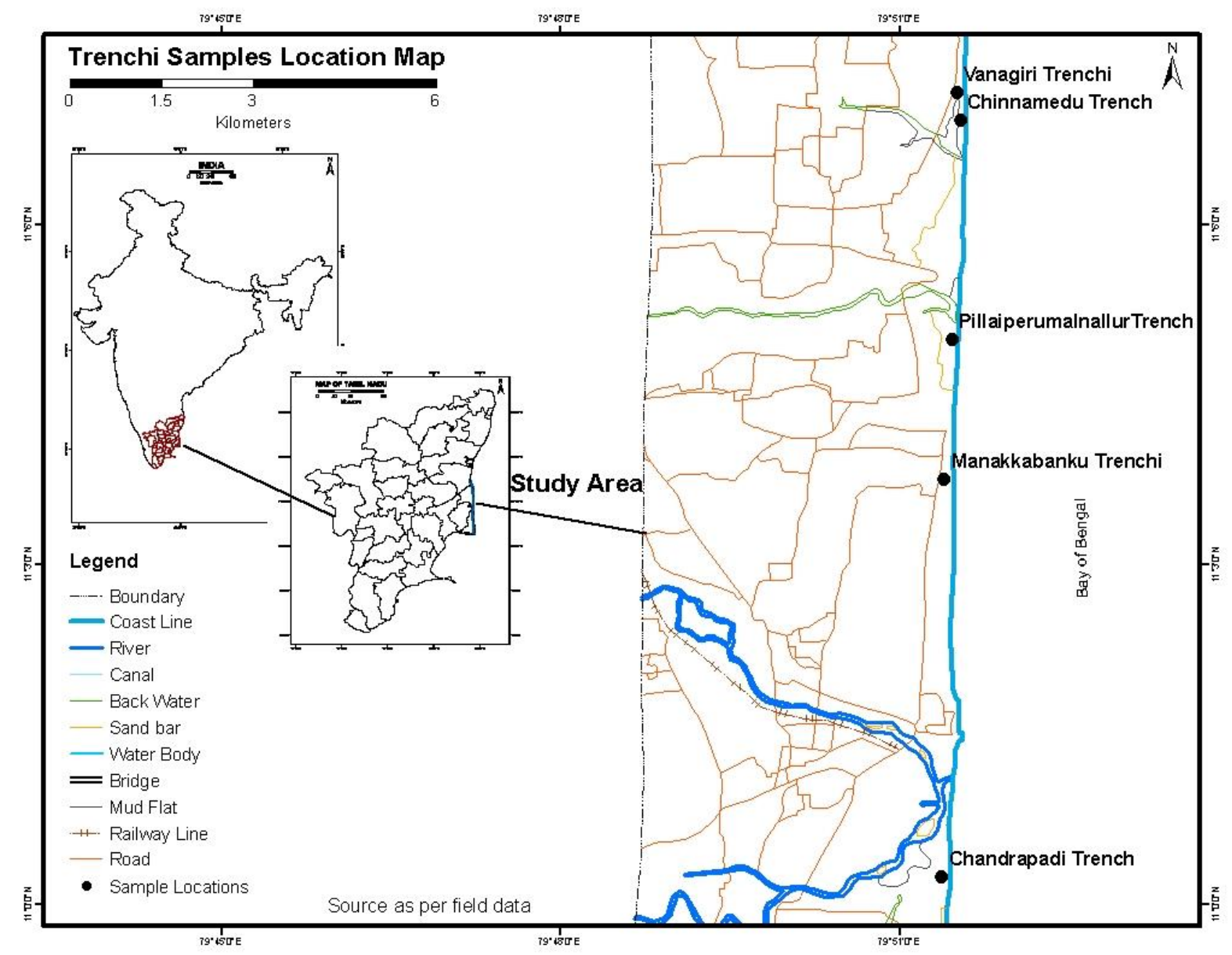

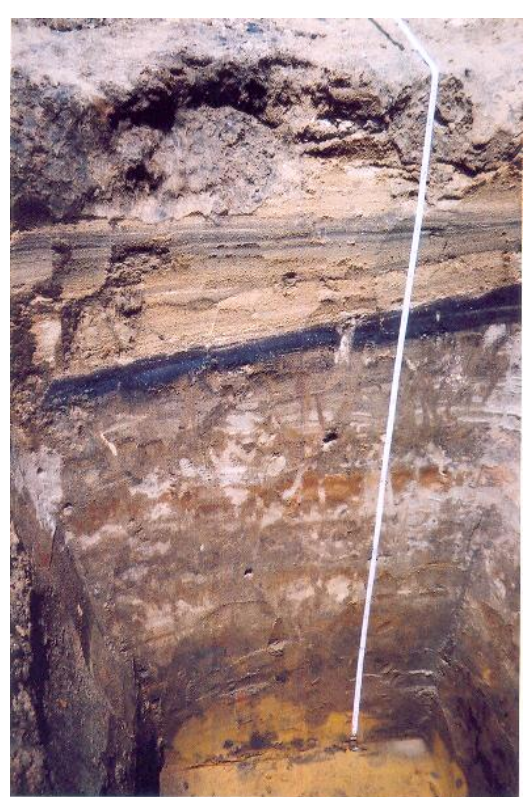

a.Chandrapadi Trench
Fig -1_Map showing Study Area

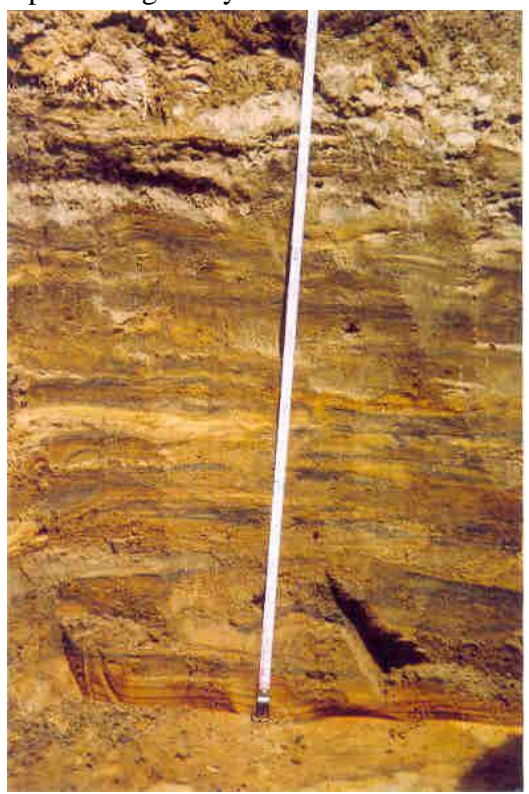

b.Vanagiri Trench 
International Journal of Science and Engineering Applications

Volume 1 Issue 1, 2012

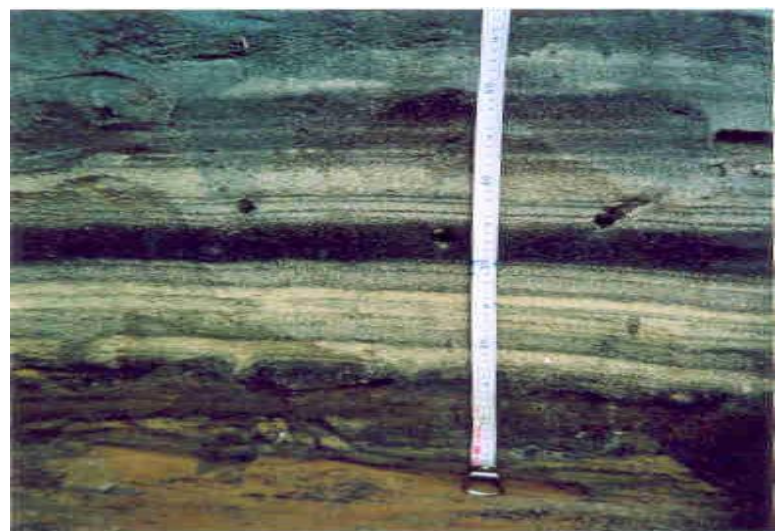

c.Chinnamedu Trench

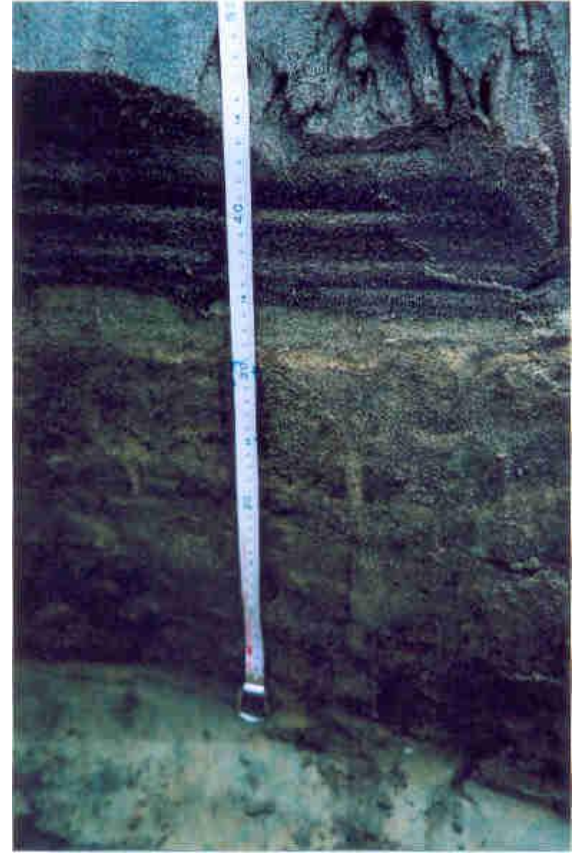

b.Pillaiperumanallur Trench

Fig-2_Trench photographs a Chandrapadi, b Vanagiri, c Chinnamedu, d Pillaiperumanallur

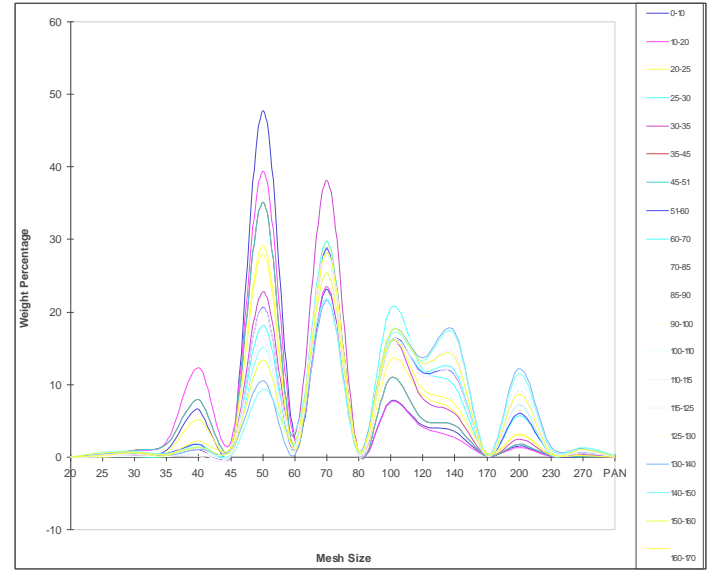

a.Chandrapadi-Trench

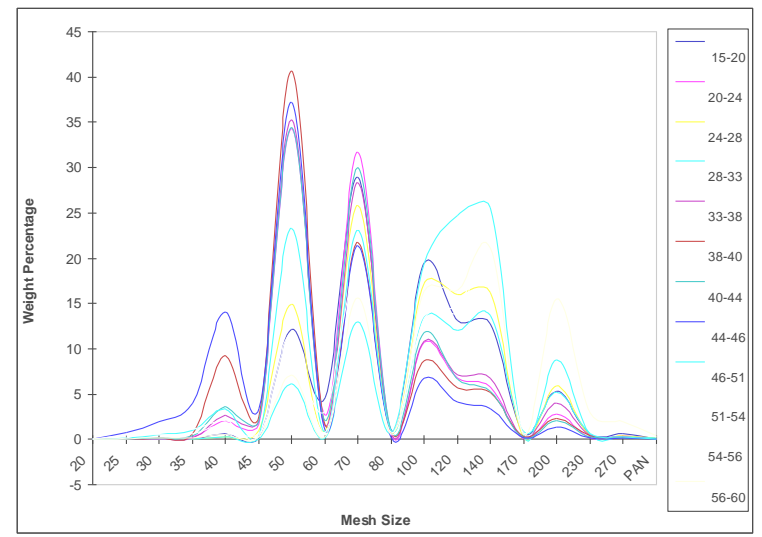

c.Cinnamaedu Trench

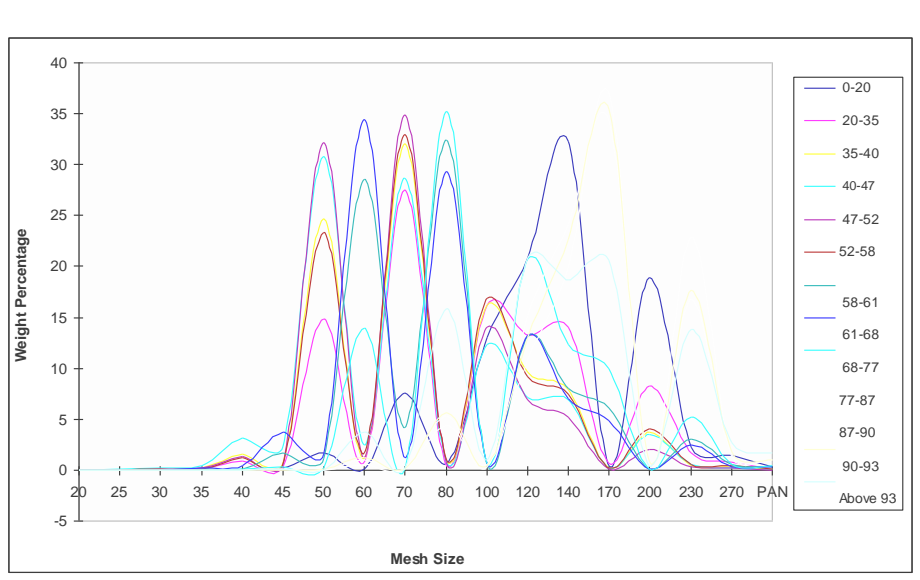

b.Manickapangu Trench

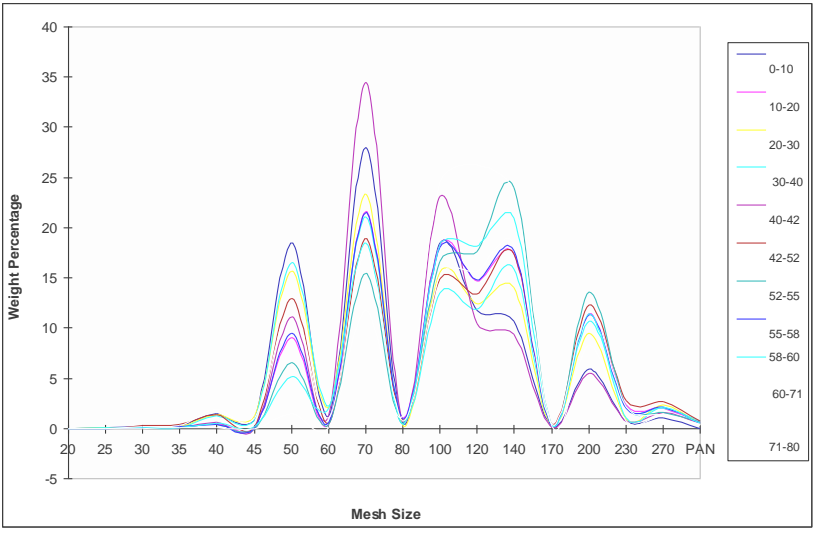

d.Vanagiri Trench 


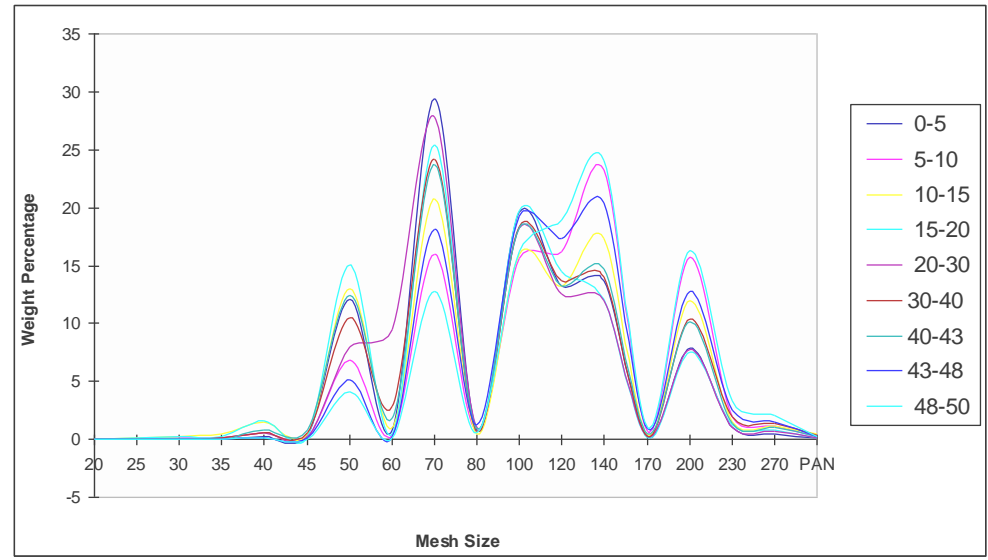

e.Pillaiperumanallur Trench

Fig - 3 Frequency curves a Chandrapadi, b Manickabangu, c Chinnamedu,d Vanagiri, e Pillaiperumanallur

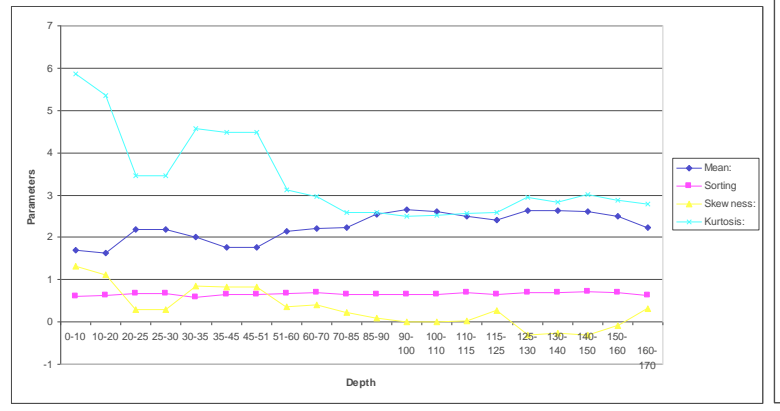

a.Chandrapadi-Trench

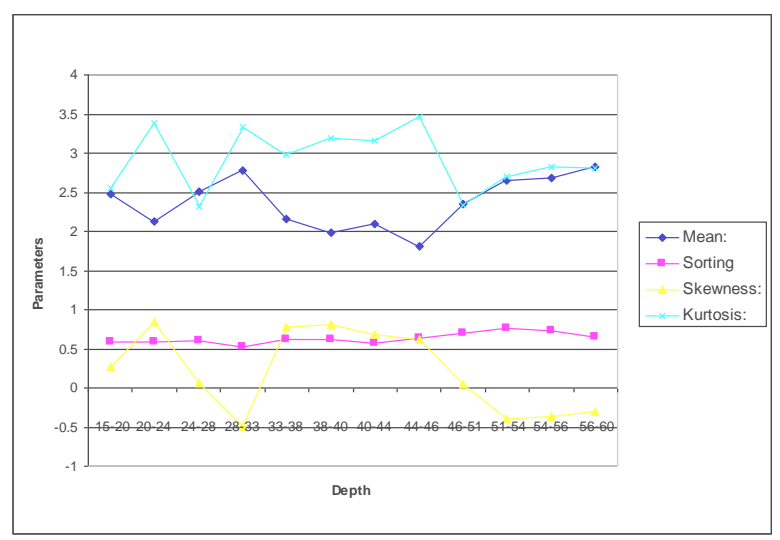

\section{c.Cinnamaedu Trench}

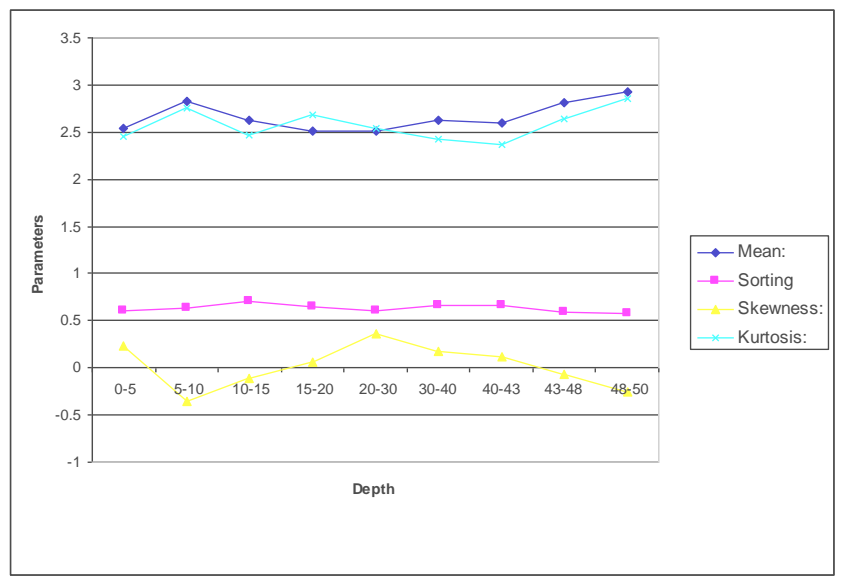

e.Pillaiperumanallur Trench

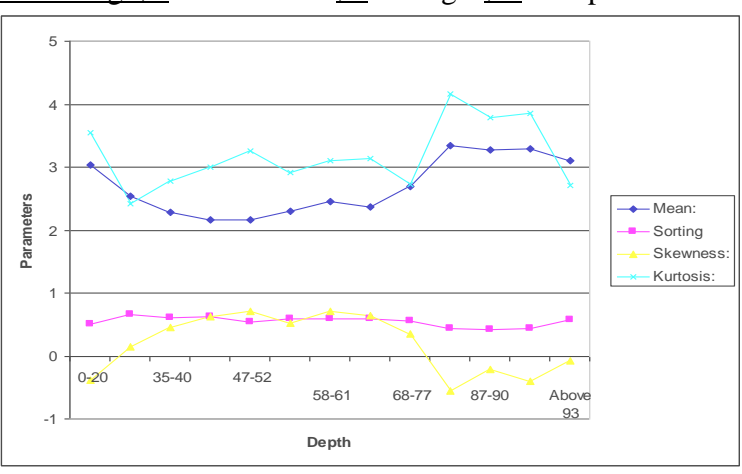

b.Manickapangu Trench

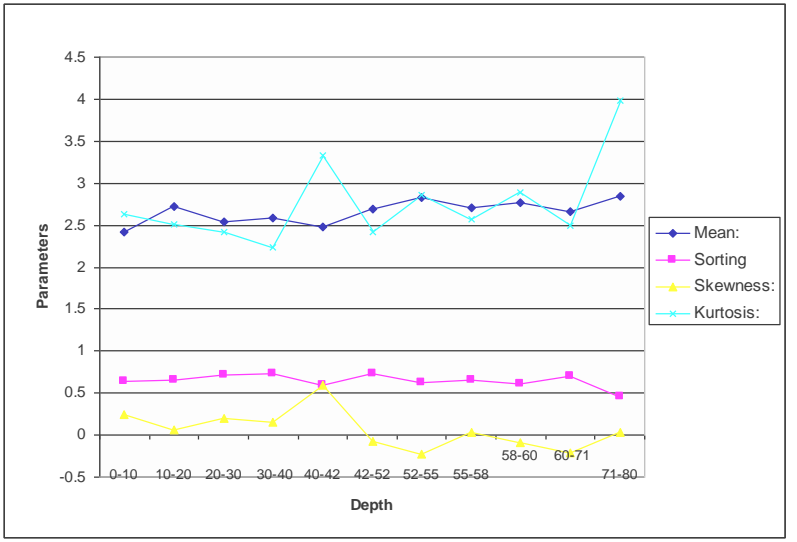

d.Vanagiri Trench 
Fig - 4 Distribution pattern shown by Statistical parameters a Chandrapadi, b Manickabangu, c Chinnamedu, d Vanagiri,e

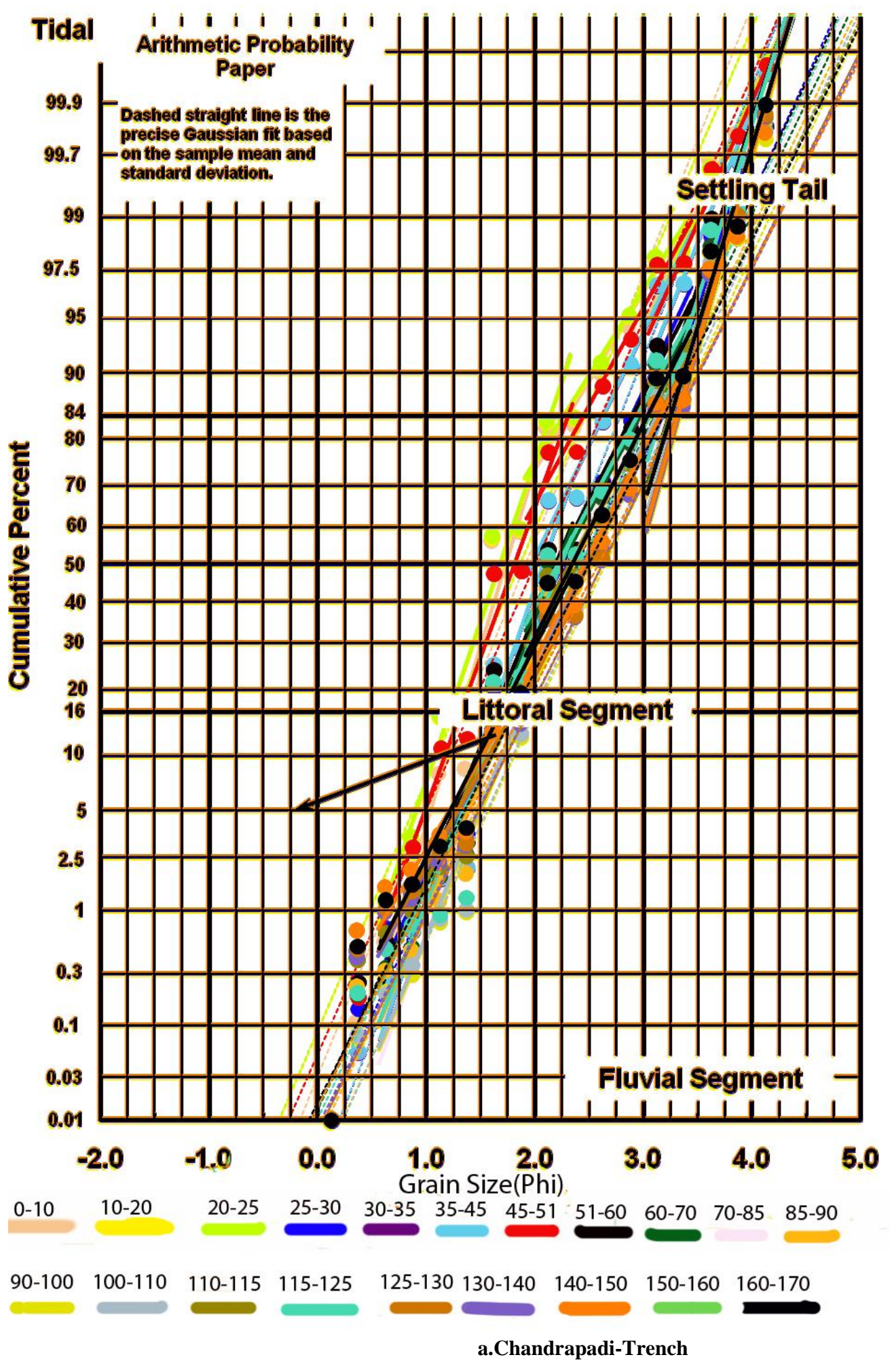



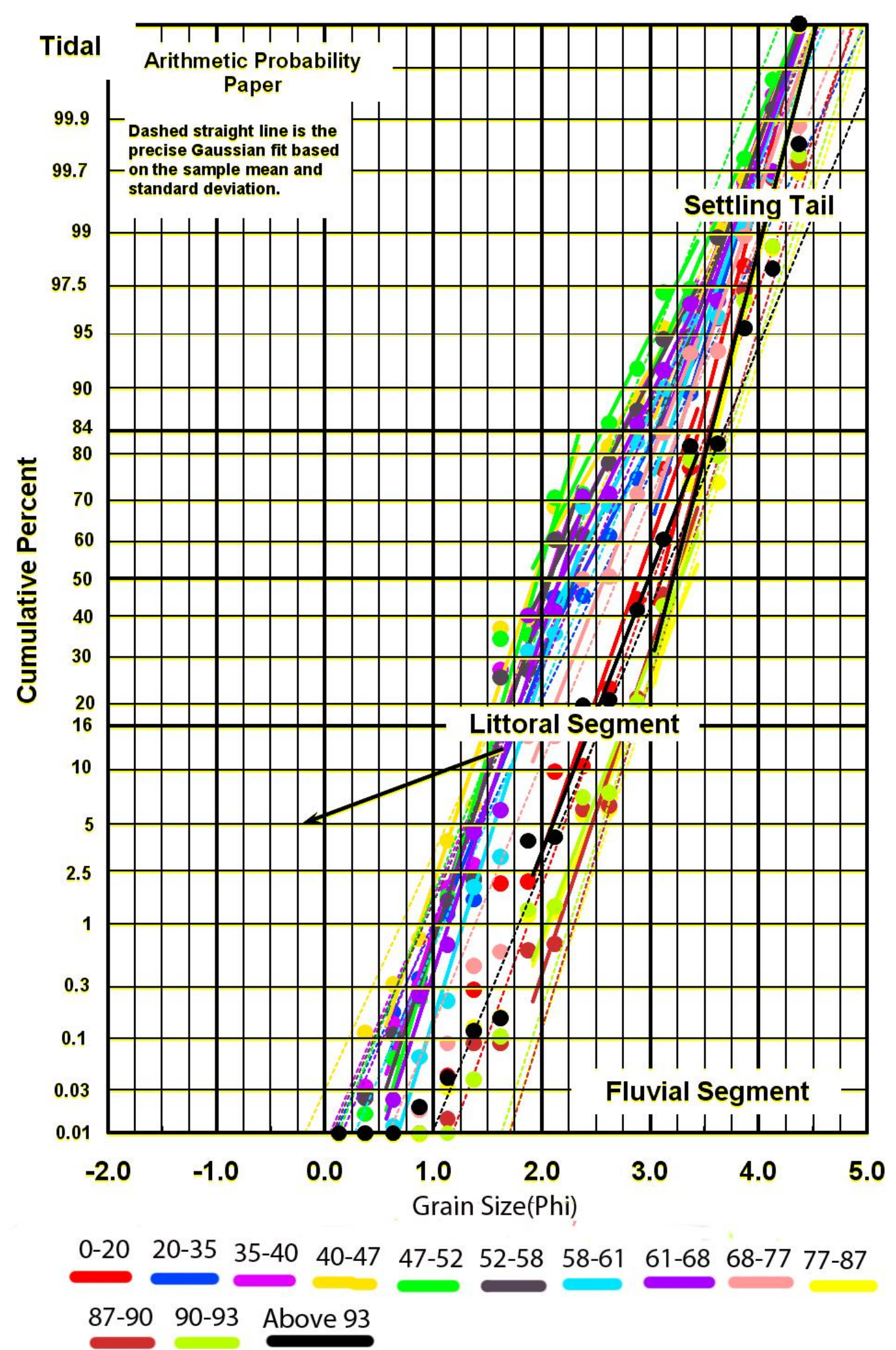

b.Manickapangu Trench 


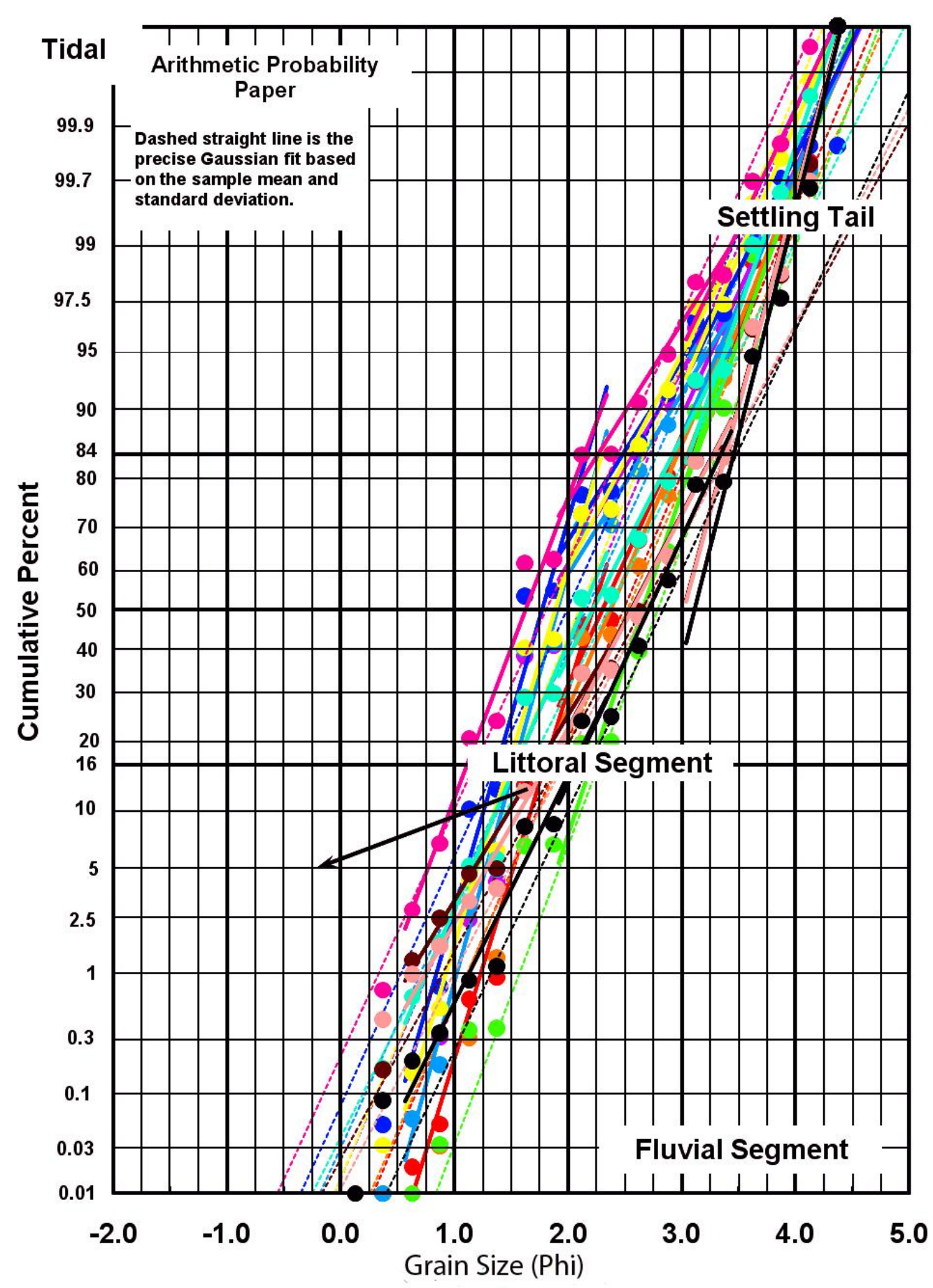

$\begin{array}{lllllllllll}15-20 & 20-24 & 24-28 & 28-33 & 33-38 & 38-40 & 40-44 & 44-46 & 46-51 & 51-54\end{array}$

54-56 56-60

c.Cinnamaedu Trench 


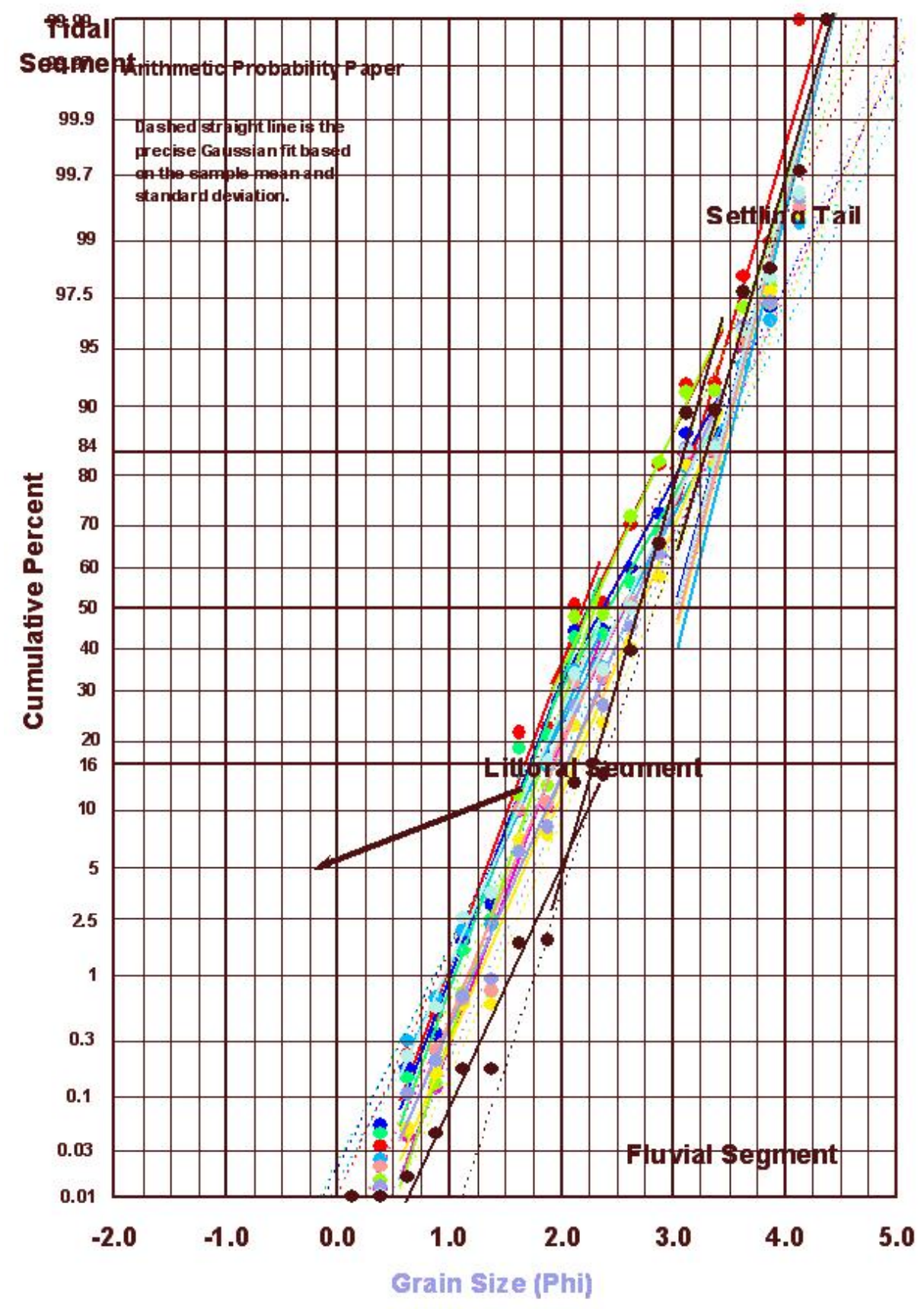

$\begin{array}{lllllll}0-10 & 10-20 & 20-30 & 30-40 & 40-42 & 42-52 & 52-55\end{array}$

55-58 $58-60 \quad 60-71 \quad 71-80$

d.Vanagiri Trench 


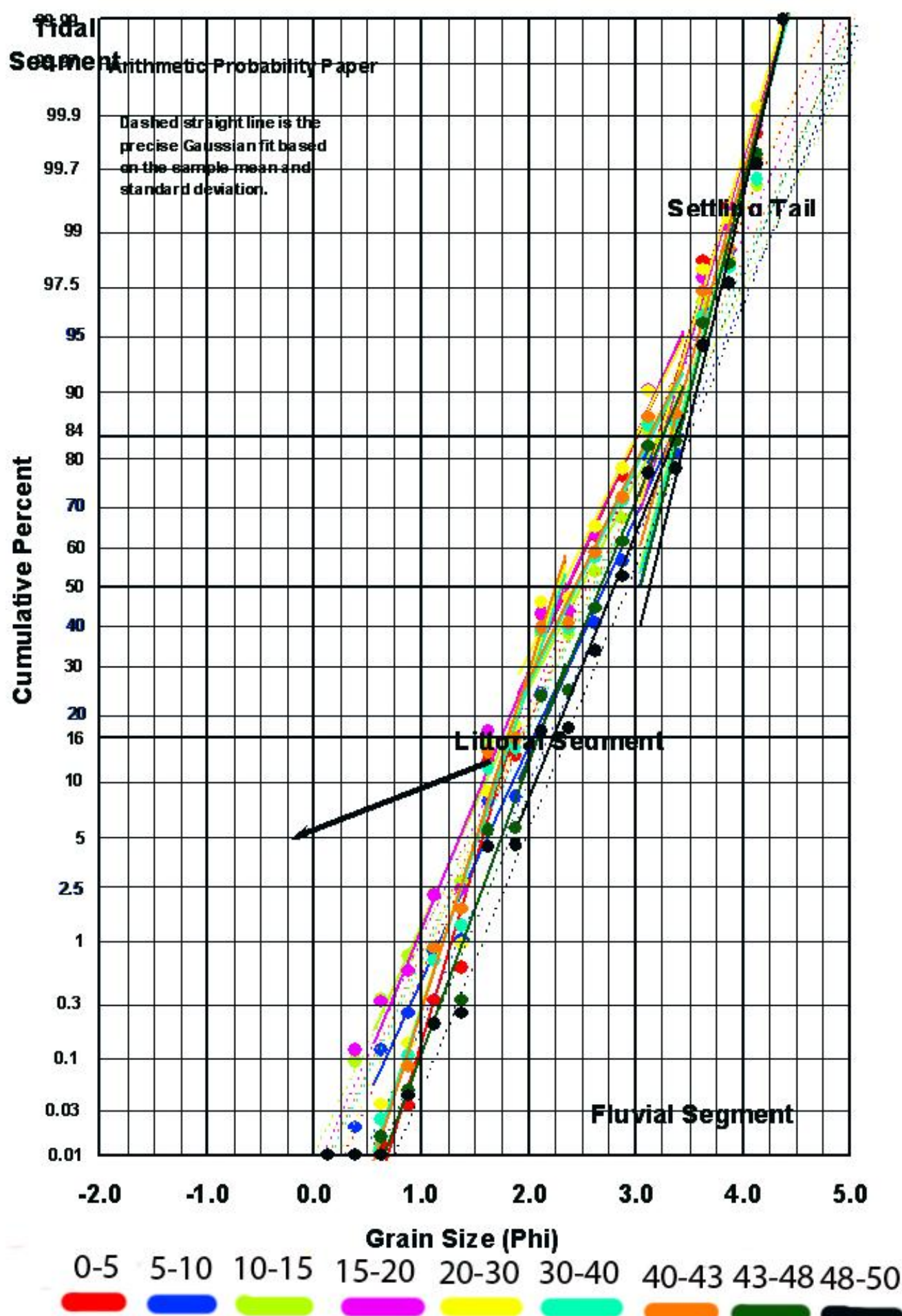

Fig - 5 Visher's diagram a Chandrapadi, b Manickabangu, c Chinnamedu, d Vanagiri, e Pillaiperumanallur 


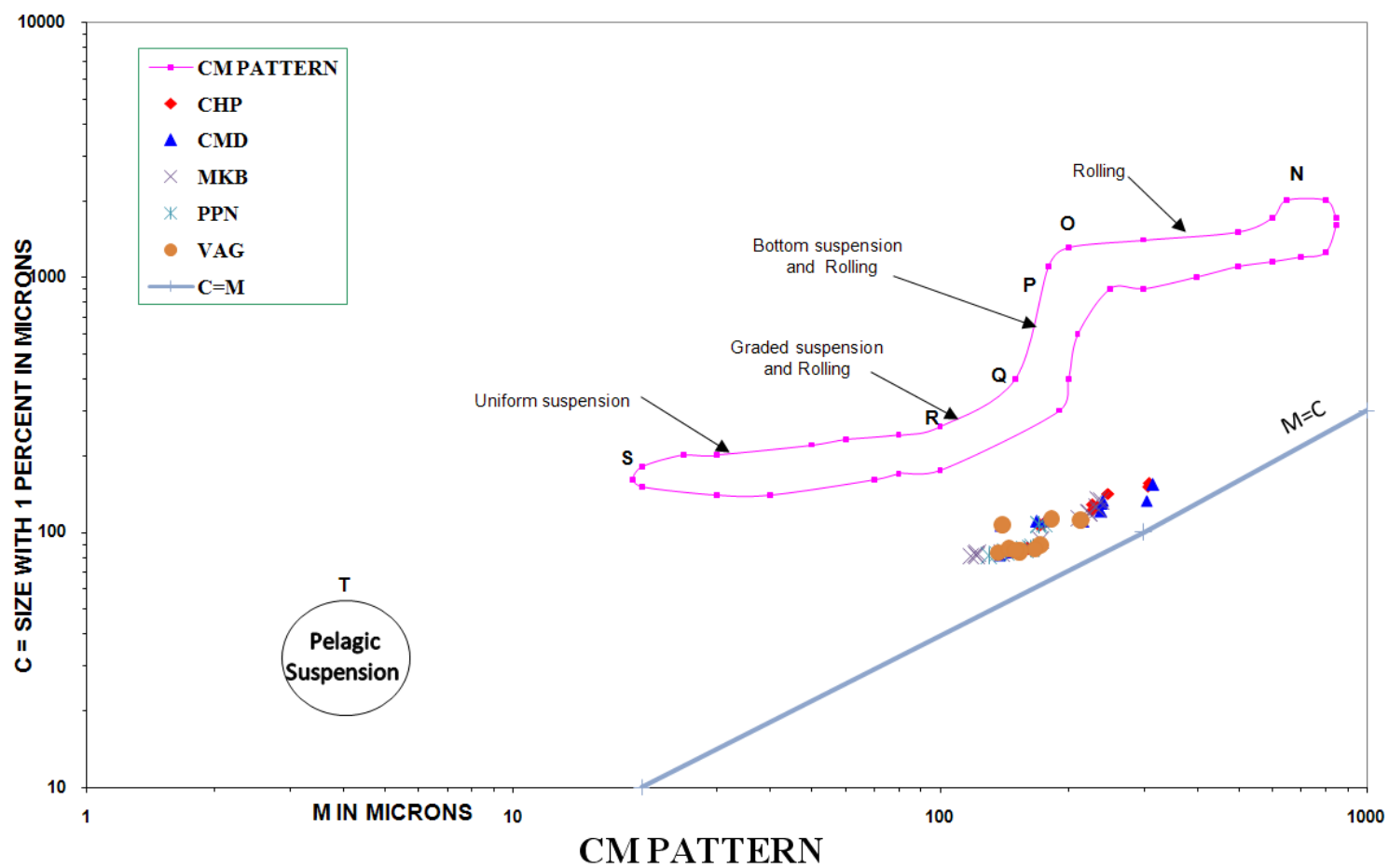

a. CM Pattern with full view

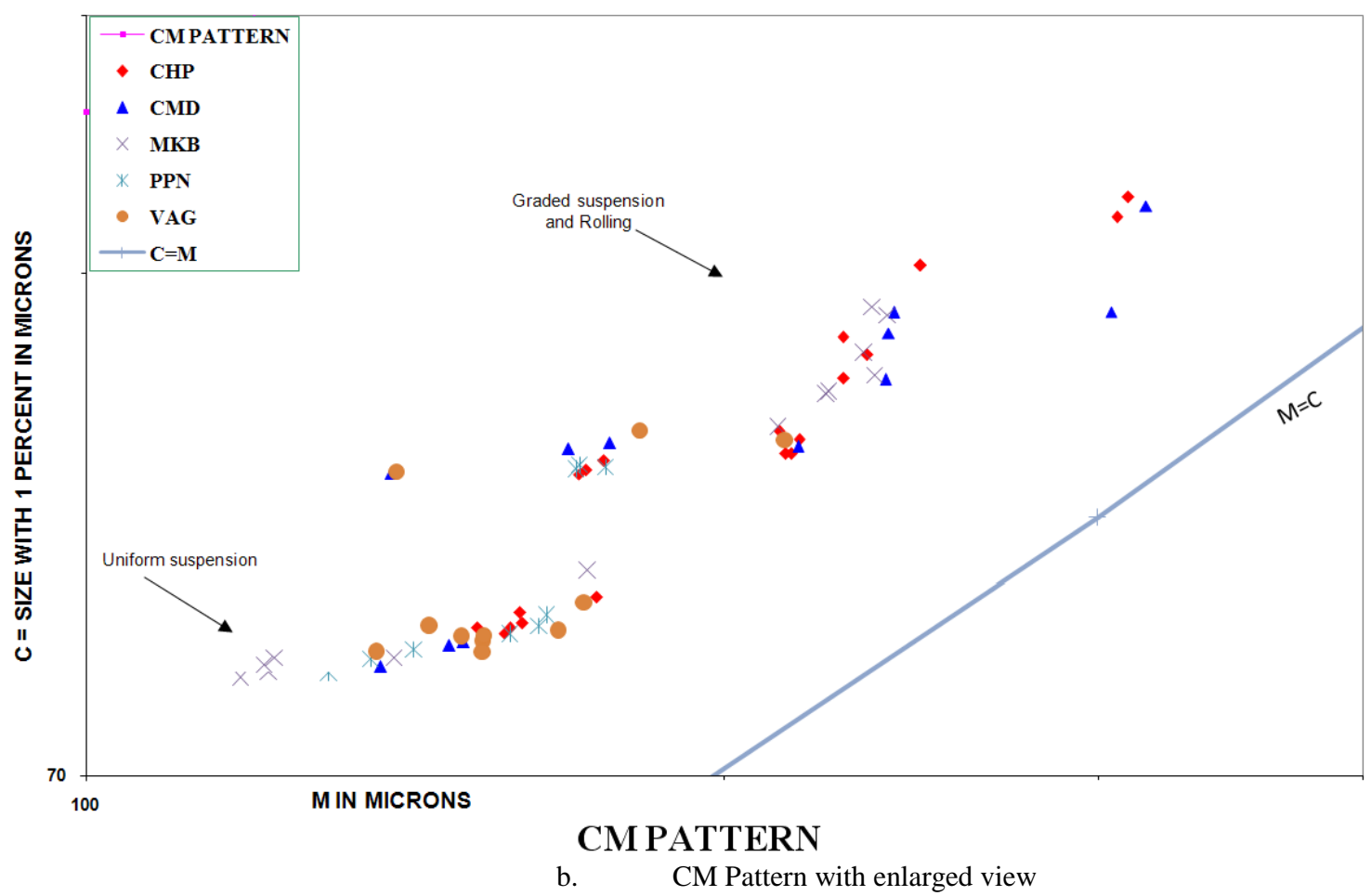

Fig -6 a. Log probability plot of 1st Percentile $\mu \mathrm{m}$ 'C' vs Median $\mu \mathrm{m}$ 'M' after Passega 1964 b. Enlarged view. 
International Journal of Science and Engineering Applications

Volume 1 Issue 1, 2012

Dendrogram using Average Linkage (Between Groups)

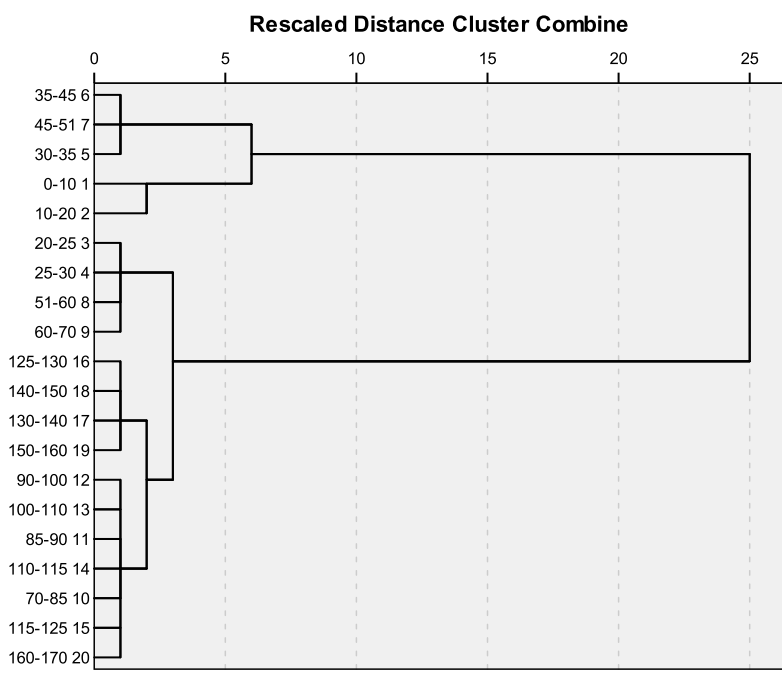

a.Chandrapadi-Trench

Dendrogram using Average Linkage (Between Groups)

\begin{tabular}{|c|c|c|c|c|c|}
\hline \multicolumn{6}{|c|}{ Rescaled Distance Cluster Combine } \\
\hline 0 & 5 & $\begin{array}{c}10 \\
\end{array}$ & $\begin{array}{c}15 \\
\end{array}$ & 20 & 25 \\
\hline
\end{tabular}

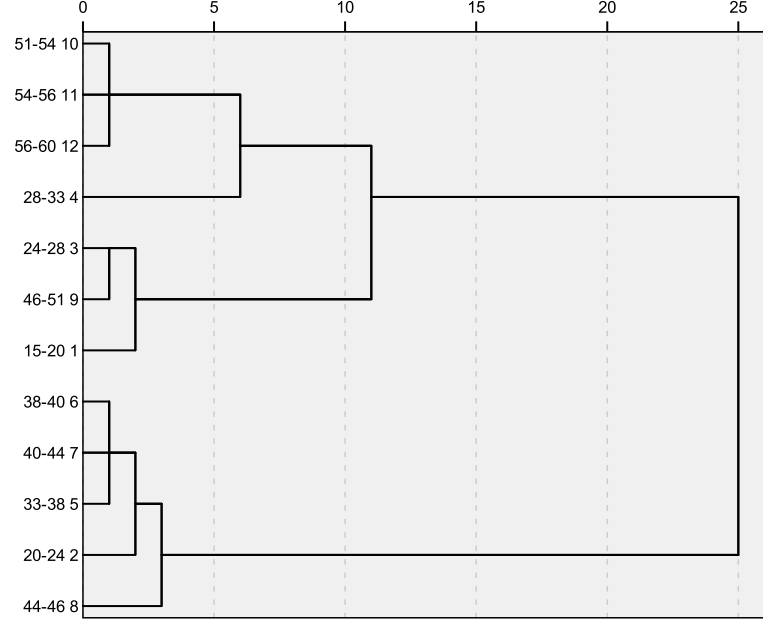

c.Cinnamaedu Trench
Dendrogram using Average Linkage (Between Groups)

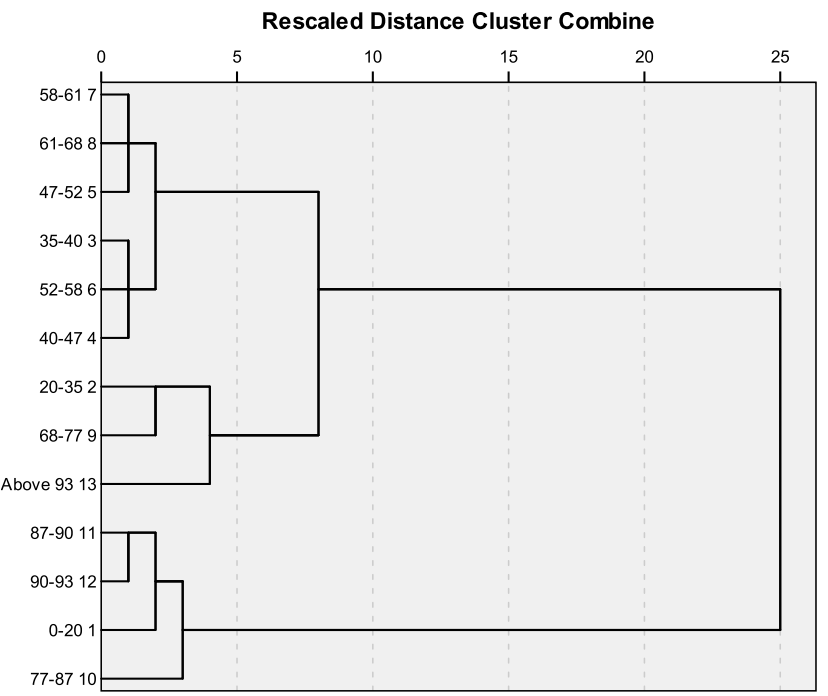

b.Manickapangu Trench

Dendrogram using Average Linkage (Between Groups)

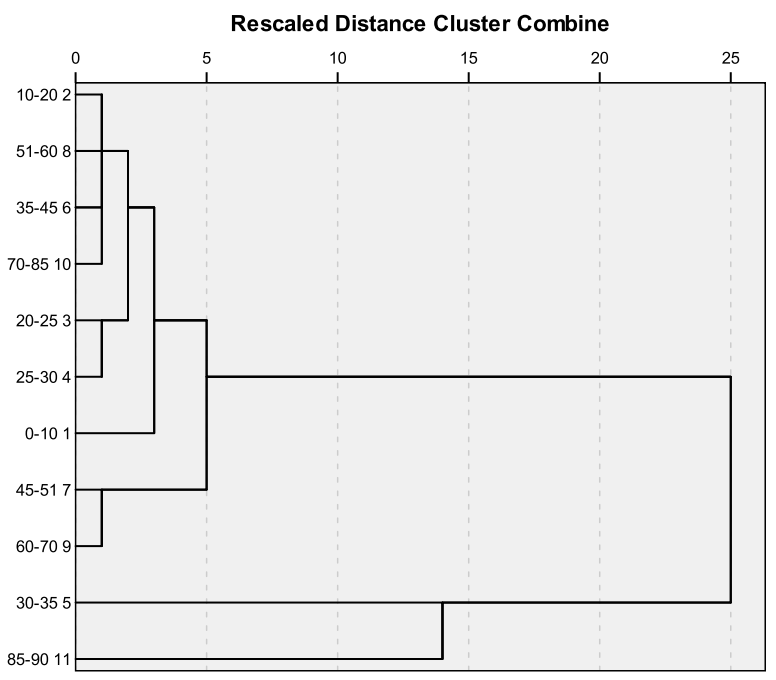

d.Vanagiri Trench 
International Journal of Science and Engineering Applications

Volume 1 Issue 1, 2012

Dendrogram using Average Linkage (Between Groups)

Rescaled Distance Cluster Combine

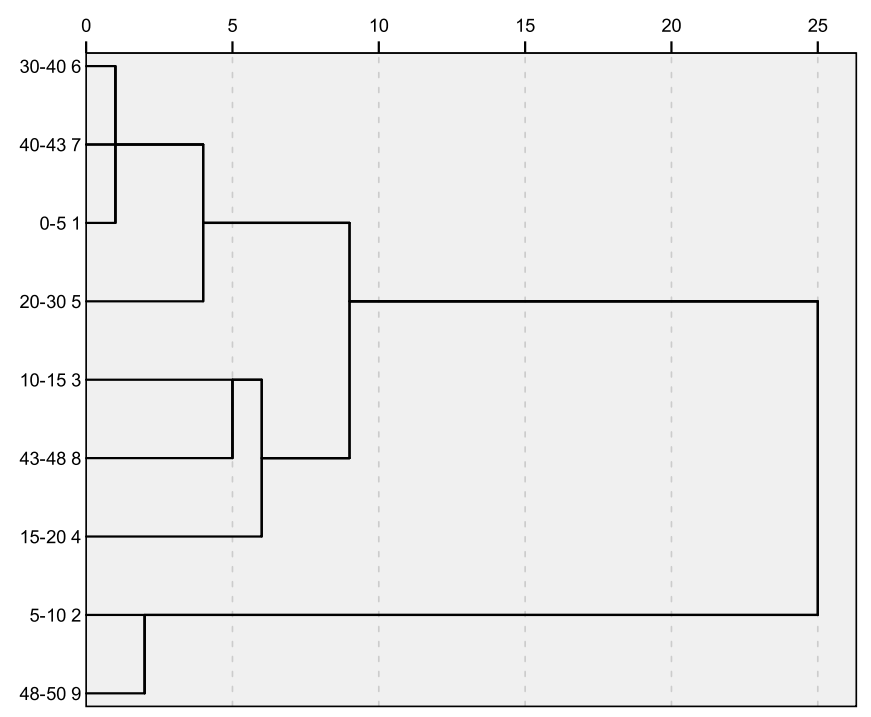

e.Pillaiperumanallur Trench

Fig - 7 Hierarchial Cluster diagram a Chandrapadi, b Manickabangu, c Chinnamedu, d Vanagiri, e Pillaiperumanallur 